\title{
A Era Lula/Tamborzão política e sonoridade
}

\author{
Guillermo Caceres $^{1}$ \\ Lucas Ferrari ${ }^{2}$ \\ Carlos Palombini ${ }^{3}$
}

\section{Resumo}

Uma série de episódios que mostram o comprometimento do primeiro presidente petista com a militarização da segurança pública serve de pano de fundo para um estudo da origem, do desenvolvimento e da morfologia de três bases rítmicas características de três décadas sucessivas do Funk Carioca: o Volt Mix (anos 1990), o Tamborzão (primeira década dos anos 2000) e o Beatbox (anos 2010). Entrevistas, transcrições e espectrogramas indicam sincronismos entre transformações da sonoridade e eventos políticos. À medida que se cerceiam os bailes, a base desocupa sucessivamente o agudo (primeira década dos anos 2000) e o grave (anos 2010) para encolherse no centro. O início e o fim do segundo mandato, marcados pela Chacina do Pan (2007) e pela invasão dos Complexos da Penha e do Alemão (2010), delimitam uma era de ouro do Proibidão.

\section{Palavras-chave}

Funk carioca, baile funk, volt mix, tamborzão, beatbox.

Recebido em 12 de novembro de 2013

Aprovado em 12 de março de 2014

CACERES, Guillermo; FERRARI, Lucas; PALOMBINI, Carlos. A Era Lula/Tamborzão: politica e sonoridade. Revista do Instituto de Estudos Brasileiros, Brasil, n. 58, p.157-207, jun. 2014.

$1 \quad$ Universidade Federal do Ceará (UFC, Sobral, CE, Brasil)

2 Universidade Federal de Minas Gerais (UFMG, Belo Horizonte, MG, Brasil)

3 Universidade Federal de Minas Gerais (UFMG, Belo Horizonte, MG, Brasil) 


\title{
The Age of Lula/Tamborzão Politics and Sonority
}

\author{
Guillermo Caceres \\ Lucas Ferrari \\ Carlos Palombini
}

\begin{abstract}
A series of episodes that show president Luiz Inácio Lula da Silva's commitment to the militarization of public security provides the backdrop for a study of the origin, development and morphology of three beats (bases) that characterize, each, one decade of Funk Carioca: Volt Mix (1990s), Tamborzão (the years 2000-2009) and Beatbox (from 2010 onwards). Interviews, transcriptions and spectrograms indicate synchronisms between political events and changes in sonority. As the dances (bailes) become outlawed, the beat retreats successively from the high (years 2000-2009) and low (2010 to date) edges of the spectrum to concentrate in the medium. Marked by the Pan American Games Massacre of 2007 and by occupation of the Penha and Alemão complexes of favelas in 2010, the beginning and the end of Luiz Inácio Lula da Silva's second term in office delimit a golden age of Forbidden Funk (Proibidão).
\end{abstract}

Keywords

Funk carioca, baile funk, volt mix, tamborzão, beatbox. 
Nunca como neste momento, quando é a própria vida que se vai, se falou tanto em civilização e cultura. E há um estranho paralelismo entre esse esboroamento generalizado da vida que está na base da desmoralização atual e a preocupação com uma cultura que nunca coincidiu com a vida e é feita para reger a vida. (Antonin Artaud, 1938) ${ }^{4}$

Aqui veio a polícia, veio a UPP, veio o teleférico, agora tem que vim escola, tem que vim creche, tem que vim cultura... (Luiz Inácio Lula da Silva, 2010) ${ }^{5}$

A fome de significado e valorização é mais funda e mais radical que a fome física. A cooptação pelo crime é mais que uma operação meramente contábil. Não se trata apenas de saber quem dá mais, mas qual a natureza daquilo que se recebe e que função o bem visado pode cumprir, no imaginário e no mundo afetivo dos jovens guerreiros. (Luís Eduardo Soares, 2007) ${ }^{6}$

4. ARTAUD, Antonin. Préface: le théâtre et la culture. In: Le Théatre et son double. Paris: Gallimard, 1938. Trad. Teixeira Coelho; . Prefácio: o teatro e a cultura. In: O teatro e seu duplo. São Paulo: Martins Fontes, p. 1-8, 1993, p. 1.

5 SILVA, Luiz Inácio Lula da. Discurso do Presidente da República, Luiz Inácio Lula da Silva, durante visita ao Complexo do Alemão. Biblioteca da Presidência da República, Brasília, 21 dez. 2010. Disponível em: <http://goo.gl/JSp5p4>. Acesso em: 10 ago. 2013. Transcrito conforme gravação apresentada no telejornal da Rede Record, 21 dez. 2010. Disponível em: <http://youtu.be/16Q2d_JqMmU>. Acesso em: 19 ago. 2013 .

6 SOARES, Luís Eduardo; GUINDANI, Miriam. A violência do Estado e da sociedade no Brasil contemporâneo. Nueva Sociedad: Democracia y política en América Latina, Buenos Aires, n. 2o8, mar.-abr. 2007. Disponível em: <http://goo.gl/ExEt5G>. Acesso em: 10 ago. 2013. 


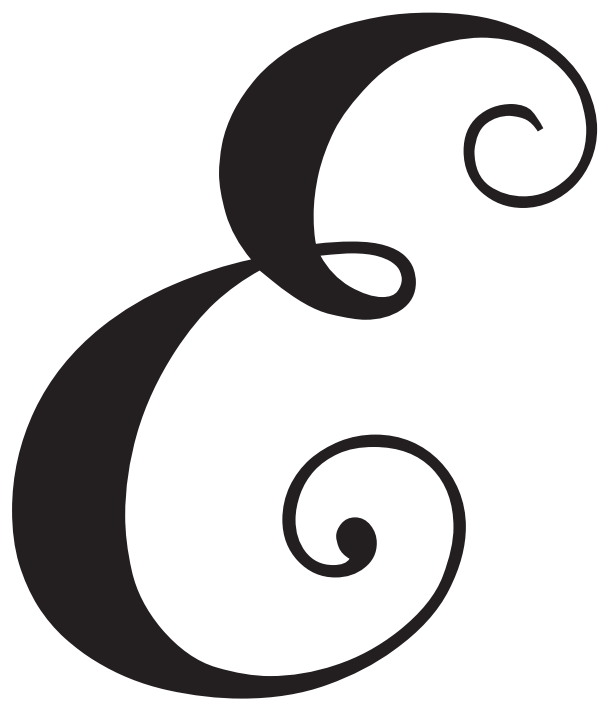

\section{Em meu fim está meu começo}

$\mathrm{m}$ aparência incongruentes no que diz respeito à questão da segurança pública, dois discursos marcam o começo e o fim dos oito anos de Luiz Inácio Lula da Silva na presidência da República. Aos quatro meses do primeiro mandato, em Vitória, ele declara na companhia do ministro da Justiça, Márcio Thomaz Bastos, e do secretário nacional de segurança pública, Luís Eduardo Soares:

Hoje nós enfrentamos uma indústria, eu diria até multinacional, do crime organizado. Ele tem o seu braço na política, tem o seu braço na polícia, tem o seu braço no poder Judiciário, tem o seu braço nos empresários, tem o seu braço internacional. Então, é uma coisa muito poderosa que, de vez em quando, nós vemos na televisão: "Polícia consegue apreender a maior quantidade de cocaína já vista no Brasil”. Aí o que apresenta a televisão? Cinco ou seis "bagrinhos". Para onde ia e de onde veio, quem vendeu e quem comprou a droga, não aparece. Aparecem os "bagrinhos", ou seja, é sempre a mesma história.

E nós só vamos combater o crime organizado quando a gente resolver pegar quem compra e quem vende, e não apenas quem está no processo de intermediação, que muitas vezes são pobres coitados, induzidos para ganhar o pão de cada dia. Às vezes a gente pega e ouve na televisão o seguinte discurso: "Tem violência? Tem. Vamos cercar a favela. Tem droga? Tem. Vamos ocupar a favela”. Possivelmente, no dia em que a inteligência da Polícia for mais ousada e mais forte do que a força bruta, a gente não precise 
invadir uma favela, mas, quem sabe, subir numa cobertura, numa das grandes capitais deste país, e pegar um verdadeiro culpado pelo narcotráfico. ${ }^{7}$

A onze dias do término do segundo mandato, no teleférico do Complexo do Alemão (uma obra do Programa de Aceleração do Crescimento), o presidente discursa em companhia do governador Sérgio Cabral e do prefeito Eduardo Paes:

Eu que assisti à ocupação do Morro do Alemão pela televisão me emocionei. Imagino você, governador Sérgio Cabral, o que sentiu quando viu, pela primeira vez, o povo assistindo à polícia entrar como amiga. O povo viu as Forças Armadas servindo ao brasileiro. Não para atacar ou bater no povo, mas para defendê-lo dos verdadeiros bandidos do país. Um dado concreto é o seguinte: o Complexo do Alemão não é mais bicho-papão. O Complexo do Alemão é na verdade um cenário de estação para que o povo possa viver com mais satisfação. ${ }^{8}$

Entre o início do primeiro mandato e o final do segundo, "um verdadeiro culpado pelo narcotráfico" é substituído pelos "verdadeiros

[N.A.] Exceto pelos fragmentos de Artaud, em epígrafe, e de Benjamin, em epílogo, os textos em línguas estrangeiras são dados em nossas traduções. As transcrições musicais em notação tradicional são de Lucas Ferrari. As análises de espectro foram realizadas por Carlos Palombini no programa Acousmographe. Guillermo Caceres identificou os samples individuais e reconstituiu a base Tamborzão numa bateria eletrônica idêntica àquela usada pelo DJ Luciano Oliveira, além de ter participado das análises de produções musicais. As entrevistas aparecem em transcrições livres a partir de gravações dos depoimentos orais, em sua maior parte disponíveis nos endereços fornecidos.

7 SILVA, Luiz Inácio Lula da. Discurso do Presidente da República, Luiz Inácio Lula da Silva, na cerimônia de assinatura de Protocolo de Intenções e Repasse de Recursos da União para o Espírito Santo, para a área da segurança pública. Biblioteca da Presidência da República, Brasília, 22 abr. 2003, p. 4-5. Disponível em: <http://goo. gl/xba851>. Acesso em: 10 ago. 2013.

8 SILVA, Luiz Inácio Lula da. Discurso do Presidente da República, Luiz Inácio Lula da Silva, durante visita ao Complexo do Alemão. Biblioteca da Presidência da República, Brasília, 21 dez. 2010. Disponível em: <http://goo.gl/RSjfUF $>$. Acesso em: 10 ago. 2013. O excerto citado não consta no texto, mas foi divulgado na imprensa. ABDALA, Vitor. Para Lula, Complexo do Alemão não é mais "bicho-papão". Agência Brasil, Brasília, 21 dez. 2010. Disponível em: <http://goo.gl/mSkhXB >. Acesso em: 10 ago. 2013. A frase final não aparece nem na versão da Biblioteca da Presidència da República, nem na matéria de Abdala, mas foi registada pela Globo News. Disponível em: <http://youtu.be/zCguZSDPaPg>. Acesso em: 19 maio 2014. 
bandidos do país", cujo domicílio já não é "uma cobertura, numa das grandes capitais deste país", mas o Complexo do Alemão.

Neste artigo expomos uma seleção de episódios que marcam a militarização da segurança pública durante o primeiro e o segundo mandatos, discorremos sobre as bases rítmicas que caracterizam três épocas da música funk carioca, e constatamos sincronismos entre fatos políticos e transformações da sonoridade.

\section{Plano Nacional de Segurança Pública}

Em fevereiro de 2002, o presidente do Instituto Cidadania e précandidato à presidência da República pelo Partido dos Trabalhadores, Luiz Inácio Lula da Silva, apresenta, no Palácio do Congresso, o Plano Nacional de Segurança Pública, elaborado por Antonio Carlos Biscaia, Benedito Mariano, Roberto Aguiar e Luís Eduardo Soares durante mais de um ano de trabalho conjunto no Instituto. Através de consultas a gestores, pesquisadores, especialistas e profissionais de diferentes disciplinas e instituições, e a lideranças da sociedade em todas as partes do país, o Plano incorporava experiências bem sucedidas no Brasil e no estrangeiro. Ele repelia jargões ideológicos, assumia posição não-partidária e almejava contribuir para a construção de um consenso mínimo na suposição de que segurança pública fosse matéria, não de governo, mas de Estado, e se situasse acima de querelas político-partidárias. Ao sagrar-se candidato, Luiz Inácio Lula da Silva o integra a seu Programa de Governo. Eleito, designa Luiz Eduardo Soares para a Secretaria Nacional de Segurança Pública, com o objetivo de criar as condições necessárias para implementá-lo em seis etapas: 1) construção de um consenso entre os governadores; 2) desconstitucionalização das polícias ${ }^{9}$ e normatização do Sistema Único de Segurança Pública (Susp); 3) instalação, em cada estado, de Gabinetes de Gestão Integrada da Segurança Pública, braço operacional do Susp; 4) negociação com o Banco Mundial e o Banco Interamericano de Desenvolvimento em vista de um aporte, por sete anos, de três bilhões e meio de dólares a juros subsidiados; 5) envio ao Congresso Nacional da emenda da desconstitucionalização das polícias e, como matéria infraconstitucional, da normatização do Susp;

9 Referência ao Art. 144 da Constituição, no qual se definem organização, funções e jurisdições das polícias. CONSTITUINTE, Assembleia Nacional. Constituição da República Federativa do Brasil. Diário Oficial da União, Brasília, 5 out. 1988. Disponível em: <http://goo.gl/QSSau8>. Acesso em: 18 ago. 2013. 
6) convocação dos 27 governadores para a celebração do Pacto pela $\operatorname{Paz}^{10}$. Os governadores dispõem-se a colaborar e assinam a carta de intenções, mas o presidente não confirma a participação do governo. Soares explica em retrospecto:

Se o presidente tivesse convocado os governadores para a celebração do Pacto, completaríamos as etapas quatro e cinco quase automaticamente sem maiores traumas - a despeito de dificuldades naturais, mas certamente superáveis, considerando-se a força política então do presidente, além da liderança dos governadores. O presidente reviu sua adesão ao Plano e desistiu de prosseguir no caminho previsto porque percebeu - na interlocução com a instância que, à época, se denominava "núcleo duro do governo" que fazê-lo implicaria assumir o protagonismo maior da reforma institucional da segurança pública no país, ou seja, implicaria assumir a responsabilidade pela segurança perante a opinião pública. E isso o exporia a riscos políticos, pois a responsabilidade por cada problema, em cada esquina, de cada cidade, lhe seria imputada. O desgaste seria inevitável, uma vez que os efeitos práticos de uma reorganização institucional só se fariam sentir a longo prazo. ${ }^{11}$

Em outubro de 2003 o secretário deixa a secretaria - e com ela, o governo e o partido - num escândalo político com características de intriga palaciana, alardeada nos jornais $O$ Globo, Folha de S. Paulo, O Dia, Correio Braziliense e Zero Hora, bem como nas revistas Época e Isto $E^{12}$. Eis a trama ${ }^{13}$ : funcionários do ministério da Justiça preparam

10 SOARES, Luiz Eduardo. A Política Nacional de Segurança Pública: histórico, dilemas e perspectivas. Estudos avançados, São Paulo, v. 21, n. 61, p. 77-97, dez. 2007, p. 87-88. Disponível em: <http://goo.gl/OKEL7g>. Acesso em: 11 ago. 2013. DOI: http://dx.doi.org/10.159o/s0103-4014,2007000zoooo6

11 Idem, p. 88.

12 Para uma lista de matérias jornalísticas, ver BARROSO, Edson Wagner de Sousa; MEDEIROS, Silvana Canuto. Representação contra Luís Eduardo Soares junto ao excelentíssimo senhor presidente nacional do Partido dos Trabalhadores, deputado José Genoíno. Brasília, s.d. Disponível em: <http://goo.gl/RsjQOZ> e <http:// goo.gl/MTfgGF>. Acesso em: 11 ago. 2013. Ver também MELILO J. \& ASSOCIADOS. Representação contra Luís Eduardo Soares junto ao excelentíssimo senhor doutor juiz de Direito da Vara Criminal da circunscrição judiciária de Brasília. Brasília, 19 nov. 2003. Disponível em: <http://goo.gl/MUfKzX > e <http://goo.gl/WnMxMl>. Acesso em: 11 ago. 2013.

13 Cf. MEIRELLES, Andrei. Fogo cruzado na segurança. Época, São Paulo, n. 284, p. 42-43, 27 out. 200z. Disponível em: <http://goo.gl/NQpJ9a>. Acesso em: 12 ago. 2013. 
um dossiê contra o secretário; o dossiê chega à Casa Civil; que o transmite ao ministro da Justiça; que quer demitir o secretário; o comando do partido opõe-se; $O$ Globo publica o dossiê em 21 de outubro; o presidente do partido informa ao secretário que a situação é insustentável; o secretário renuncia. E denuncia: o dossiê foi elaborado, com consulta a documentos internos confidenciais, por dois policiais civis petistas que ele mesmo trouxera para a Secretaria ${ }^{14}$. O ministro afirma que a saída do secretário não acarretará mudança na segurança pública ${ }^{15}$. Anos depois, Soares o desmente:

O plano do primeiro mandato do presidente Lula não foi implementado. O governo federal preferiu não correr o risco do desgaste e não chamar para si a responsabilidade de liderar as grandes transformações estruturais assinaladas no plano. Fez o mesmo que criticara nos antecessores. Para desviar as atenções do recuo, lançou a Polícia Federal em operações espetaculares, levando a mídia a tiracolo. Como criticar o governo, na área da segurança, se a PF ocupava as manchetes com ações nunca vistas contra os ricos? Ante a pirotecnia que nem sempre se mostrou juridicamente sustentável, quem se lembrou de perguntar pela reforma da polícia, o Sistema Único de Segurança Pública, o piso salarial nacional, o controle da corrupção, da tortura e das execuções extrajudiciais ${ }^{16}$

\section{Força Nacional de Segurança Pública}

Após a saída de Luiz Eduardo Soares, o ministro da Justiça, Márcio Thomaz Bastos, concebe a Força Nacional de Segurança Pública, criada pelo Decreto 5.289/2004, de 29 de novembro, da subchefia para assuntos jurídicos da Casa Civil da Presidência da República, para atuar "em

Para uma análise linguística, ver KUWAE, Luiza Hiroko Yamada. O papel da mídia na construção social do escândalo político. 2006. 153 f. Dissertação (Mestrado em Linguística) - Instituto de Letras, Universidade de Brasília, 20o6. Disponível em: <http://goo.gl/8OIdJO>. Acesso em: 7 maio 2014.

14 O jornal O Dia identificou e nomeou esses funcionários; ver CÉSAR, Arnaldo. Informe do Dia. O Dia, Rio de Janeiro, 29 out. 2003, p. 4, apud BARROSO, Edson W. de S.; MEDEIROS, Silvana C. op. cit.; e MELILLO J. \& ASSOCIADOS. op. cit. MEIRELLES, Andrei. op. cit., p. 43.

16 SOARES, Luiz Eduardo. Segurança Pública no Brasil, hoje: muitos sertões, poucas veredas. O Estado de Minas, Belo Horizonte, 18 set. 2010. Disponível em: <http:// goo.gl/gZ8m8v >. Acesso em: 16 ago. 2013 . 
atividades destinadas à preservação da ordem pública e da incolumidade das pessoas e do patrimônio" (Art. $2^{\circ}$ ). Ela "poderá ser empregada em qualquer parte do território nacional, mediante solicitação expressa do respectivo Governador de Estado ou do Distrito Federal" (Art. $4^{\circ}$ ). Episódico e planejado, esse emprego será determinado pelo ministro de Estado da Justiça (Art. $4^{\circ}, \$ 1$ ). Seu contingente mobilizável

será composto por servidores que tenham recebido, do Ministério da Justiça, treinamento especial para atuação conjunta, integrantes das polícias federais e dos órgãos de segurança pública dos estados que tenham aderido ao programa de cooperação federativa. (Art. $4^{\circ}, \mathbb{\$} 2$ )

Cláudio de Souza Neto ${ }^{17}$ apontou erros formais que colocariam em questão a constitucionalidade do Decreto 5.289, mas considerou-os sanados pela Lei 11.473, de 10 de maio de 2007. Para Souza Neto, se a Força Nacional afronta a interpretação taxativa ${ }^{18}$ - preponderante no Supremo Tribunal Federal - do Art. 144 da Constituição, é a interpretação que deve ser revista: a Força constituiria uma importante inovação institucional cooperativa e teria "o mérito de reduzir a pressão autoritária pela mobilização inconstitucional das Forças Armadas". ${ }^{19}$ Para João Rodrigues Arruda, no entanto, trata-se de "mais um coelho tirado da cartola dos juristas de plantão". Ele previu problemas. Por exemplo:

a regra inicial para fixação da competência é que o crime seja julgado no local em que foi praticado. No caso de crime cometido por integrante da Força Nacional, sendo o autor policial militar de estado diverso daquele em que foi praticado o crime, será ele julgado pela justiça militar do estado onde estava atuando? ${ }^{20}$

Passados nove meses da publicação do Decreto 5.289, o novo secretário, Luiz Fernando Corrêa, anuncia que o projeto para os Jogos

17 SOUZA NETO, Cláudio Pereira de. A segurança pública na Constituição Federal de 1988: conceituação constitucionalmente adequada, competências federativas e órgãos de execução das políticas. Atualidades jurídicas, Brasília, n. 1, mar./abr. 20o8, p. 47-48. Disponível em: <http://goo.gl/sNtWa4>. Acesso em: 15 ago. 2013.

18 É taxativo "tudo o que é determinado de modo expresso, ou de modo restrito, para que não se permita qualquer ampliação ou generalidade". SILVA, De Plácido e. Vocabulário jurídico. 28. ed., Rio de Janeiro: Forense, 2oog, p. 1.356.

19 SOUZA NETO, Claudio P. de. op. cit., p. 48.

20 ARRUDA, João Rodrigues. O uso político das Forças Armadas e outras questões militares. Rio de Janeiro: Mauad, 2007, p. 110. 
Pan-americanos de 2007 está pronto para ser aprovado pelo Gabinete da Casa Civil. Dez mil homens estarão disponíveis para o evento, se solicitados pelo governador do estado ${ }^{21}$. Quando, em janeiro de 2007, Luiz Inácio Lula da Silva assina o compromisso constitucional pela segunda vez no Congresso, Sérgio Cabral Filho o faz pela primeira, na Assembleia Legislativa do Estado. Na mesma data, o chefe do executivo fluminense solicita informalmente ao Palácio do Planalto o envio imediato da Força Nacional de Segurança Pública ao Rio de Janeiro ${ }^{22}$.

\section{Chacina do Pan}

A ocupação do Complexo do Alemão e da Vila Cruzeiro ocorreu por meio de ações isoladas, em fevereiro, e continuadas, durante dois meses, entre maio e julho de 2007. Na terça-feira, 13 de fevereiro, a Força Nacional deu apoio à Coordenadoria de Recursos Especiais da Polícia Civil (Core) e ao Batalhão de Operações Especiais da Polícia Militar (Bope) em ação conjunta que resultou em seis mortos e dois feridos. O comandante da Força Nacional, coronel Aurélio Ferreira, considerou a ação bem sucedida: "dentro do que foi planejado, cumprimos nosso papel. Continuamos à disposição do governo do Rio". ${ }^{25} \mathrm{Na}$ quarta-feira, 27 de junho, a operação contou com a participação de 1.350 agentes policiais, utilizou 1.080 fuzis, consumiu 180 mil balas, durou cerca de oito horas e resultou na apreensão de quatorze armas, cinquenta explosivos e 2 mil balas, supostamente em poder de traficantes. A Chacina do Pan ou Massacre do Alemão ${ }^{24}$ coroou com um saldo oficial de dezenove mortos e sessenta feridos no cerco

21 AGÊNCIA BRASIL. Rio-2007 terá 10 mil homens da Força Nacional. Terra, zo ago. 2005. Disponível em: <http://goo.gl/bZiI8v>. Acesso em: 13 ago. 2013.

22 REUTERS. Cabral pede envio imediato da Força Nacional de Segurança ao Rio. GI, Rio de Janeiro, 1 jan. 2007. Disponível em: < http://goo.gl/oKIb2A >. Acesso em: 13 ago. 2013.

23 GRUPO ESTADO. Força Nacional faz patrulha no Complexo do Alemão, no Rio. Estado de S. Paulo, São Paulo, 14 fev. 2007. Disponível em: <http://goo.gl/WtGXqo>. Acesso em: 2 nov. 2013.

24. Ver Alvarenga FILHo, José Rodrigues de. A “Chacina do Pan" e a Produção de Vidas Descartáveis na Cidade do Rio de Janeiro. 2010. 316 f. Dissertação (Mestrado em Psicologia) - Centro de Filosofia e Ciências Humanas, Universidade Federal Fluminense, 2010. Disponível em: <http://goo.gl/32N2dm7 >. Acesso em: 4, mar. 2014. 
iniciado em 2 de maio ${ }^{25}$. A Associação de Moradores da Grota contabilizou 21 vítimas fatais ${ }^{26}$.

No sábado, 7 de julho, o jornal $A$ Nova Democracia percorreu a Grota e o Morro do Alemão para ouvir os moradores. E mostrou crimes de Estado perpetrados com a cumplicidade, a conivência ou a omissão interessada do presidente da OAB-RJ, Wadih Damous (atual presidente da Comissão Nacional de Direitos Humanos da OAB e da Comissão da Verdade do Rio de Janeiro), do presidente da Comissão de Direitos Humanos da Alerj, deputado Alessandro Molon (futuro pré-candidato do PT à prefeitura municipal), e das ONGs AfroReggae e Cufa. "No mesmo dia, à noite", completou Marcelo Salles, "os oito postos vagos no tráfico varejista já haviam sido repostos". ${ }^{27}$ Para o Centro de Mídia Independente (CMI Brasil), Maurício Campos descreveu "uma clássica operação militar de cerco e aniquilamento com ordens de não fazer prisioneiros, [...] algo condenado até pelas convenções de Genebra". ${ }^{28}$ Dias depois Luiz Inácio Lula da Silva discursava no Rio ${ }^{29}$.

Agora, essa ação de vocês no Complexo do Alemão, tem gente que acha que é possível enfrentar a bandidagem com pétalas de rosas, jogando pétalas de rosas, jogando pó-de-arroz. A gente tem que enfrentar os bandidos, sabendo que estão, muitas vezes, mais preparados do que a polícia, com armas mais sofisticadas do que a polícia. ${ }^{30}$

25 BALDEZ, Miguel et al. Manifesto pela apuração das violações de direitos humanos cometidas na operação Complexo do Alemão. Abong: Organização em defesa dos direitos e bens comuns, São Paulo, 18 jul. 2007. Disponível em: <http://goo.gl/ DQGn95 >. Acesso em: 3 nov. 2013.

26 CANDIDO, Luciana. O Haiti é aqui, no Complexo do Alemão. Partido Socialista dos Trabalhadores Unificado, São Paulo, 29 jun. 2007. Disponível em: <http://goo.gl/ c7oNyf >. Acesso em: 2 nov. 2013.

27 SALLES, Marcelo. A chacina do Complexo do Alemão. A Nova Democracia, Rio de Janeiro, ano 6, n. 36, ago. 2007. Disponível em: <http://goo.gl/ULcpra >. Acesso em: 2 nov. 2013.

28 CAMPOS, Maurício. Complexo do Alemão, 27/o6/2007 - a primeira chacina assumida pelo Estado no Rio. Centro de Mídia Independente, Rio de Janeiro, 29 jun. 2007. Disponível em: <http://goo.gl/JtKZxs>. Acesso em: 3 nov. 2013.

29 REDE GLOBO. Lula manifesta apoio à ação da polícia em favelas do Rio. Jornal Nacional, Rio de Janeiro, 2 jul. 2007. Disponível em: <http://goo.gl/y8aRuo>. Acesso em: 2 nov. 2013 .

zo SILVA, Luiz Inácio Lula da. Discurso do Presidente da República, Luiz Inácio Lula da Silva, na cerimônia de lançamento do PAC nas áreas de saneamento e urbanização no estado do Rio de Janeiro. Biblioteca da Presidência da República, Brasília, 2 jul. 2007. Disponível em: <http://goo.gl/V5zmcL >. Acesso em: 2 nov. 2013. 
Um ano mais tarde, o relator especial de execuções extrajudiciais, sumárias ou arbitrárias da ONU, Philip Alston, ratificava as constatações de Marcelo Salles e Maurício Campos. Alston verificou que, "de fato, do ponto de vista do controle do crime, a operação foi um fracasso". ${ }^{31} \mathrm{E}$ ressaltou: “o grau em que as mortes de 'criminosos' são toleradas e até publicamente encorajadas por representantes do alto escalão do governo ajuda muito a explicar por que o número de mortos por policiais é tão alto, e essas mortes, investigadas de modo tão inadequado". ${ }^{32}$

\section{Artigo 142}

Em 28 de julho de 1988, às vésperas de ser promulgada a Constituição Federal, Luiz Carlos Prestes denunciou "o preceito mais reacionário, ou ditatorial da nova Constituição, a qual, na prática, pode a qualquer momento ser anulada ou rasgada constitucionalmente!" 33 Ele se referia ao artigo 142, que destina as Forças Armadas "à garantia dos poderes constitucionais e, por iniciativa de qualquer destes, da lei e da ordem". Uma vez que o artigo 144 não prevê esse destino ${ }^{34}$, Souza Neto interpreta conjuntamente os artigos 142 e 144 para concluir que seu emprego está reservado a situações excepcionais, quando ocorra a decretação de estado de defesa, estado de sítio ou intervenção federal. Visto haver, nas três hipóteses, restrição a direitos fundamentais e relativização da autonomia estadual, a Constituição submete as medidas aplicáveis a rigoroso controle legislativo e jurisdicional. Além disso, seus executores podem ser responsabilizados pelos ilícitos cometidos (Art. 141), e o presidente da República se arrisca a responder por crime de responsabilidade (Art. 85) por atos que atentem contra "o exercício dos direitos políticos, individuais e sociais".

31 ALSTON, Philip. Mission to Brazil (documento ONU A/HRC/11/2/Add.2). Official Documents System of the United Nations, New York, 23 mar. 2009, p. 13. Disponível em: <http://goo.gl/1Zkdho>. Acesso em: 2 mar. 2014.

32 Idem, p. 16.

33 PRESTES, Luiz Carlos. Um "poder" acima dos outros. Tribuna da Imprensa, Rio de Janeiro, 28 jul. 1988. Disponível em: <http://goo.gl/NdWogz>. Acesso em: 2 nov. 2013.

34. Sobre o uso das Forças Armadas, ver ARRUDA, João R, op. cit.; BARROSO, Luís Roberto. Forças Armadas e ações de segurança pública: possibilidades e limites à luz da Constituição. Revista de Direito do estado, Rio de Janeiro, v. 2, n. 7, p. 43-68, jul./ set. 2007. Também como: Parecer n. 2/2007 (datado de 13 jun. e aprovado pela procuradora-geral do estado em 21 ago. 2007). Revista de Direito da Procuradoria Geral, Rio de Janeiro, v. 62, p. 360-382, 2007. Disponível em: <http://goo.gl/JweoSv >. Acesso em: 5 nov. 2013; SOUZA NETO, Claudio P. de. op. cit. 
Afora essas três situações excepcionais, a Constituição Federal permite o emprego das Forças Armadas em outras duas: na realização de investigações criminais no âmbito de inquérito policial militar, e na execução de operações de policiamento ostensivo em contextos nos quais predomine o interesse nacional, especialmente em visitas de chefes de estado. No que concerne ao primeiro caso, Souza Neto faz duas ressalvas:

A primeira é a de que não há espaço, em nossa ordem constitucional, para mandados genéricos, que indiquem, por exemplo, a possibilidade de promover buscas em bairros inteiros. Sob o pretexto de realizar a apreensão de armas de uso exclusivo das Forças Armadas, autoridades militares não podem determinar a ocupação de uma favela, como já se verificou em nossa história recente $^{35}$. A segunda ressalva diz respeito à necessidade de que a diligência seja autorizada por autoridade judicial. As diligências de busca e apreensão domiciliar são submetidas à chamada "reserva de jurisdição", não podendo ser determinadas pelas autoridades militares que presidem inquéritos policiais militares, como determinava o Código de Processo Penal Militar em seu artigo 177, que foi revogado quanto a este aspecto. ${ }^{36}$

O segundo caso está disciplinado pelo artigo $5^{\circ}$ do Decreto 3.897/2001, de 24 de agosto. João Rodrigues Arruda condensa: “sob o pretexto de regulamentar a lei complementar, o decreto criou uma nova forma de intervenção federal e atribuiu poder de polícia às Forças Armadas. Um exercício de Poder Constituinte ilegítimo, com o silêncio conivente do Congresso Nacional". ${ }^{37}$

Finalmente, a legislação infraconstitucional comporta uma sexta possibilidadede emprego das Forças Armadas em operações de segurança, estabelecida em 9 de junho pela Lei Complementar 97/1999, artigo $15, \mathfrak{S} 2^{\circ}$ :

35 Souza Neto pode ter em mente a "Guerra da Rocinha”, em que a Aeronáutica e o Exército foram atacados e roubados (2004); ou a ocupação militar de diversas comunidades, inclusive a Providência, em função de um furto ocorrido num quartel em São Cristóvão. Sobre a Guerra da Rocinha, ver ARRUDA, João R. op. cit., p. 8188. Sobre o episódio de 20o6, ver FOLHA ONLINE. Exército no Rio. Folha Online. São Paulo, 12 mar. - 19 abr. 20o6. Disponível em: <http://goo.gl/nRrJUH>. Acesso em: 2 mar. 2014.

36 SOUZA NETO, Claudio P. de. op. cit., p. 36-37.

37 ARRUDA, João R. op. cit., p. 99. 
a atuação das Forças Armadas, na garantia da lei e da ordem, por iniciativa de quaisquer dos poderes constitucionais, ocorrerá de acordo com as diretrizes baixadas em ato do presidente da República, após esgotados os instrumentos destinados à preservação da ordem pública e da incolumidade das pessoas e do patrimônio, relacionados no artigo 144 da Constituição Federal.

No mesmo artigo, $\mathbb{S} 3^{\circ}$, incluído pela Lei Complementar 117/2004, de 2 de setembro,

consideram-se esgotados os instrumentos relacionados no artigo 144 da Constituição Federal quando, em determinado momento, forem eles formalmente reconhecidos pelo respectivo chefe do Poder Executivo Federal ou Estadual como indisponíveis, inexistentes ou insuficientes ao desempenho regular de sua missão constitucional.

Não seria, portanto, necessária a decretação de estado de defesa, de estado de sítio, ou de intervenção federal para realizar aquilo que, em 1824, o artigo 148 da Constituição Imperial formulava de modo mais conciso: "Ao Poder Executivo compete privativamente empregar a Força Armada de Mar, e Terra, como bem lhe parecer conveniente à Segurança, e defesa do Imperio". Souza Neto opina:

Pretende-se, com a Lei Complementar 97/1999, artigo 15, que o Executivo Federal possa executar medidas de caráter excepcional, com séria limitação da autonomia estadual, sem se submeter aos controles que a Constituição prevê para os casos de estado de defesa, estado de sítio e intervenção federal. Na verdade, significa permitir que medidas excepcionais sejam decretadas, sem que se observem as restrições constitucionalmente definidas e sem que se adotem os veículos formais adequados.

Há quase duas décadas está em curso na América Latina debate sobre o papel das Forças Armadas. Para uns, devem ser empregadas apenas na defesa do território. Para outros, devem servir ao combate ao narcotráfico. Esta última opção foi adotada, por exemplo, na Colômbia, com forte apoio dos Estados Unidos, que, de fato, são os principais interessados. Trata-se de importante questão de Estado, que deve ser seriamente apreciada. O emprego das Forças Armadas na segurança pública deve ser evitado também para permitir que se concentrem na sua principal 
destinação constitucional, que é a defesa da soberania territorial do Brasil. Convertê-las em polícia é o caminho mais curto para que isso deixe de ocorrer. ${ }^{38}$

$\mathrm{Na}$ onda de reações à Chacina do Pan, Souza Neto dedica seu ensaio "aos colegas da OAB-RJ pelos esforços que vêm empreendendo pela democratização da política de segurança no Estado do Rio de Janeiro". Dois anos depois de sua publicação em 2008, a Subchefia para Assuntos Jurídicos da Casa Civil estendeu à Marinha do Brasil e à Força Aérea Brasileira, através da Lei Complementar 136/2010, de 25 de agosto, poder de polícia para combater os delitos transfronteiriços e ambientais $^{39}$. Rodrigues Arruda resume:

Entre 1994 e 2004, além do Distrito Federal, dez estados da federação foram "visitados" por tropas militares. Os motivos foram os mais diversos: greves de policiais militares; destruição de plantações de maconha; proteção da fazenda utilizada pelo presidente Fernando Henrique Cardoso contra invasão pelo Movimento dos Trabalhadores Rurais Sem Terra; retomada da sede da Companhia Vale do Rio Doce, no sul do Pará, ocupada por garimpeiros. Isso não ocorre por acaso. Aos poucos as Forças Armadas brasileiras estão sendo amoldadas aos interesses das grandes potências, transformando-se em instituição policial. Após anos de resistência, entraram oficialmente na repressão ao tráfico de drogas e ao contrabando.

O que não foi possível no Império, graças à resistência dos oficiais, está sendo conseguido na República, com o beneplácito dos generais: transformar os militares numa versão atualizada dos capitães-do-mato. ${ }^{40}$

38 SOUZA NETO, Claudio P. de. op. cit., p. 39-40.

39 MARINHO, Bruno Costa. Mudanças trazidas ao poder de polícia das Forças Armadas por intermédio da Lei Complementar 136, de 25 de agosto de 2010. Ambito jurídico, Rio Grande, v. 13, n. 81, out. 2010. Disponível em: <http://goo.gl/tohQNk>. Acesso em: 10 nov. 2013.

40 ARRUDA, João R. op. cit., p. 18. 


\section{Cimento Social}

A Providência foi onde se verificou o maior número de abusos em 2006 ${ }^{41}$, quando, a pretexto de recuperar armas subtraídas às Forças Armadas, o Exército realizou incursões em várias comunidades ${ }^{42}$. Em dezembro de 2007, a notícia de nova ocupação encontrou-a naturalmente temerosa e revoltada. Tratava-se do projeto Cimento Social, que deveria alavancar, pelo Partido Republicano Brasileiro (do vice-presidente José Alencar), a candidatura do senador Marcelo Crivella (da Igreja Universal do Reino de Deus) à prefeitura do Rio de Janeiro, com o apoio do presidente da República ${ }^{43}$.

No início de 2007, parlamentares do PRB reuniram-se com Luiz Inácio Lula da Silva em visita de rotina para tratar de coligações e cargos. Na primeira brecha, Crivella apresentou uma fotografia do morro da Providência alterada por Photoshop: casas remodeladas, fachadas refeitas e telhados novos lado a lado com barracos decaídos. O Senador vendia ao governo a pérola de sua campanha: 782 casas recuperadas, tetos e janelas trocados, paredes repintadas, tudo revestido por placas pré-moldadas de um centímetro de espessura, prontas para resistir "ao impacto de balas de até sete milímetros e meio, a uma distância mínima de vinte metros" por "mil anos". O programa incluía rede de esgotos, centros comunitários, creches, postes de luz e melhorias nos serviços de eletricidade e telefonia, para não falar em reflorestamento.

O prefeito César Maia, do DEM, era uma pedra no meio do caminho. Para removê-la, o Planalto acolheu a ideia através de emenda parlamentar do próprio senador, sem cumprir as etapas previstas em lei. Ao invés de firmar-se o contrato do repasse de 12 milhões de reais entre o Ministério das Cidades e a prefeitura, como seria normal, estabeleceu-se um acordo de cooperação técnica entre os Ministérios das Cidades e da Defesa. Liquidadas de um só golpe a interferência da

41 Encontram-se nas páginas da Rede de Comunidades e Movimentos Contra a Violência e do CMI denúncias demasiado numerosas para serem listadas. Disponíveis em: <http://goo.gl/rGTgdI> e < http://goo.gl/DKWWPk>, respectivamente. Acesso em: 10 nov. 2013.

4,2 Sobre esse episódio, ver ARRUDA, João R. op. cit., p. 81-88.

43 Toda esta seção baseia-se no trabalho de TARDÁGUILA, Cristina. O exército, o político, o morro e a morte - Das manchetes ao esquecimento: o caso Providência faz dois anos. Revista Piauí, São Paulo, n. 46, jul. 2010. Disponível em: <http://goo.gl/cKt7 O2>. Acesso em: 10 nov. 2013. Ver também GARCIA, Tomás Coelho. Denúncias públicas contra a "violência policial" no Rio de Janeiro. 2009. 70 f. Dissertação (Mestrado em Ciências Humanas: Sociologia) - Instituto Universitário de Pesquisas do Rio de Janeiro, 2009. Disponível em: <http://goo.gl/HquP7s>. Acesso em: 10 nov. 2013. 
prefeitura e a fiscalização da Caixa Econômica, órgão competente para controlar recursos públicos destinados à habitação, ocorreu o "Leilão da Providência”.

Na ocasião em que os militares ocuparam a Providência, não existia qualquer decreto ou solicitação formal assinada pelo presidente Lula. Na melhor das hipóteses, havia uma autorização verbal. O Congresso tampouco fora informado. E as polícias do Rio não tinham decretado falência nem tinham sido declaradas incapazes. Mesmo assim, as tropas começaram a agir. $\mathrm{O}$ acordo de cooperação interministerial que validaria a operação só seria assinado quase dois meses depois. ${ }^{44}$

Às seis horas da manhã de sábado, 14 de junho de 2008, aos seis meses de ocupação, David Wilson Florêncio da Silva, Wellington Gonzaga da Costa Ferreira e Marcos Paulo Rodrigues Campos desembarcavam de táxi na praça Américo Brum, no alto do morro, vindos do baile funk da Mangueira. Do outro lado da praça um grupo de soldados notou a chegada e aventou a hipótese - infundada - de não terem pagado o taxista. Onze homens armados de pistolas e fuzis dirigiram-se aos rapazes e decidiram levá-los até a base militar ao pé do morro, no Santo Cristo, "para averiguações". Às sete e trinta, o segundo-tenente de infantaria Vinícius Ghidetti de Moraes Andrade, comandante da operação, embarcou-os num jipe para o Santo Cristo, onde o capitão Laerte Ferrari determinou a liberação do grupo.

Por volta de nove horas o tenente Ghidetti reuniu sua tropa, embarcou-a no caminhão, onde David, Wellington e Marcos Paulo já se encontravam, e levou-os ao morro da Mineira, no Complexo de São Carlos, controlado pela facção Amigos dos Amigos, rival do Comando Vermelho. O tenente Ghidetti inscreveu a sigla "CV" com tinta vermelha na testa dos rapazes e entregou-os a membros da ADA. Os jovens tentaram fugir, mas foram capturados. "De um lado, havia as armas dos criminosos. Do outro, as do Exército Brasileiro. Ficaram com os traficantes". ${ }^{45}$

Nas primeiras horas de domingo, David Wilson Florêncio da Silva, 24 anos, Wellington Gonzaga da Costa Ferreira, 19 anos, e Marcos Paulo Rodrigues Campos, 17 anos, foram encontrados no Aterro Sanitário de Jardim Gramacho.

44 TARDÁGUILA, C. op. cit.

45 Idem, ibidem. 
De acordo com o laudo do Instituto Médico Legal, Wellington tinha "19 PAFs", sigla para perfuração por arma de fogo. Um dos tiros estraçalhou seu olho direito. As mãos foram amarradas com fios de náilon que abriram sulcos profundos nos pulsos. Um plástico transparente envolvia o pescoço e a cabeça, de onde escorriam pedaços do cérebro. "Nota-se destruição total da massa encefálica e tronco-cerebral, descolada da dura-máter", escreveu o legista, referindo-se à membrana mais extensa, espessa e fibrosa do cérebro.

David levou vinte e seis tiros e foi amarrado com fios de telefone e cordas de sisal. As pernas tinham diversas fraturas, e o crânio fora fatalmente atingido. O menor Marcos Paulo morreu com dois disparos à queima-roupa. ${ }^{46}$

\section{Guerra do Rio}

As invasões da Vila Cruzeiro e do Complexo do Alemão pelas Forças Armadas e as Polícias Federal, Civil e Militar nos dias 25 e 28 de novembro de 2010 culminaram, na tarde de domingo, 28 de novembro, no hasteamento da bandeira nacional no alto do teleférico inacabado do Complexo do Alemão, marcando a retomada pelo Estado de um território que, do Estado, só conheceu o terror. Nem o chefe do varejo de substâncias ilícitas na Vila Cruzeiro, Fabiano Atanazio da Silva, nem o do Complexo, Luciano Martiniano da Silva, foram capturados, mas Frank Batista Ramos, Max Muller da Paixão Pessanha, Fabiano Batista Ramos, Anderson Romualdo Paulino e Wallace Ferreira da Mota - os MCs Frank, Max, Tikão, Dido e Smith - tiveram ordem de prisão decretada e foram presos ou se entregaram em meados de dezembro. Enquanto os cinco continuavam ilegalmente detidos, o presidente da República selava sua aliança com o governador do estado, Sérgio Cabral Filho, a quem se dirigia, diante do prefeito do município, Eduardo Paes, ao "testar" o teleférico do Alemão na terça-feira, 21 de dezembro.

O presidente que, no início do primeiro mandato, propugnara "subir numa cobertura, numa das grandes capitais desse país, e pegar um verdadeiro culpado pelo narcotráfico" vai encontrar "os verdadeiros bandidos do país” no Alemão ao final do segundo, e seu partido implicado numa sucessão de escândalos e investigações. O mais popular dos presidentes do Brasil não enxerga o povo: senta-se diante da televisão e

46 Idem, ibidem. 
imagina o governador a fazer o mesmo. Foi pela televisão que "o povo viu as Forças Armadas servindo ao brasileiro". Dado concreto omitido, as operações incluíram, cometidas pelo Estado, violações de domicílio, saques, extorsões, assassinatos, tortura, ocultamento de cadáveres e todo o tipo de infrações à Constituição, à Lei, aos direitos fundamentais, humanos, individuais. O presidente enxerga ali "o pobre sendo tratado com dignidade e com respeito". ${ }^{47}$ E preconiza: "agora tem que vim cultura". Mas ele ignora a cultura urbana, desconhece a revolta e a raiva da juventude suburbana ${ }^{48}$. "O meu povo quer casa, emprego, comida, e vocês só me mandam o PAC?” - perguntaram os MCs Mag e Smith ${ }^{49}$. O presidente "manda" no freestyle: "o Complexo do Alemão já não é mais bicho-papão, o Complexo do Alemão é na verdade um cenário de estação para que o povo possa viver com mais satisfação".

Entre os dias 14 e 16 de dezembro, os MCs Frank, Max, Tikão, Dido e Smith são detidos através de uma ordem de prisão temporária decretada pelo Juiz de Direito da Vigésima Oitava Vara Criminal da Comarca do Rio de Janeiro. Ao meio-dia de sábado, 15 de dezembro, Ana Paula Araújo fala dos estúdios da Rede Globo no RJTV"50: "Começamos o RJ de hoje com uma reportagem exclusiva ${ }^{51}$ que traz essas imagens aqui cedidas pela Polícia". O baile ocorreu "lá no conjunto de favelas do Alemão depois da ocupação!" Frank e Tikão “foram presos hoje de manhã dentro de uma operação da Polícia de combate a funkeiros que fazem apologia ao crime". ${ }^{52} \mathrm{Na}$ externa, o repórter Eduardo Tchau

47 EFE BRASIL, Agência. No Rio, Lula inaugura teleférico e recebe homenagens. Canal EFE Brasil, Rio de Janeiro, 21 dez. 2010. Disponível em: <http://youtu. be/6y5bAuIjFrc>. Acesso em: 20 maio 2014.

48 Como Boaventura de Sousa Santos observará sobre o PT dois anos depois. SANTOS, Boaventura de Sousa; ARELLANO ORTIZ, Fernando. El neoliberalismo facilitó secuestro del derecho por las transnacionales, hasta el punto que la legalidad va a la par com la ilegalidade. Cronicón: El observatorio latino-americano, Bogotá, fev. 2012. Disponível em: <http://goo.gl/w9qV7c>. Acesso em: 3 nov. 2013.

49 MAG, MC; SMITH, MC. Manifesto. Canal Edu Noleto, Youtube, 25 dez. 2010. Disponível em: <http://youtu.be/aU7rlkMoLF4 >. Acesso em: 20 maio 2014. A postagem mais antiga da música, no Youtube, data de 4 de junho de 2010. A vídeo-montagem citada alude ao episódio da prisão dos cinco MCs.

5o A postagem dessa edição do RJTV tornou-se um hit, com mais de um milhão de visitas no Youtube. Disponível em: <http://youtu.be/u2gOzl_Hn78>. Acesso em: 20 maio 2014.

51 Os itálicos sublinham os tons da indignação moral de uma emissora cujas técnicas de locução se forjaram na construção da ditadura, sem distinção entre telejornalismo e teledrama.

52 Para o jurista Nilo Batista, o "crime de apologia” é claramente inconstitucional. BATISTA, Nilo; GRANJA, Patrick. Nilo Batista fala sobre as UPPs e a presença do exército no Complexo do Alemão. A Nova Democracia, Rio de Janeiro, 16 nov. 2011. Disponível em: <http://youtu.be/pJBsDkJEHFw>. Acesso em: 20 maio 2014. 
informa, incorretamente: “os MCs Frank e Tikão cantam um funk sobre o chefe da facção criminosa que dominava o Alemão, Fabiano Atanazio, conhecido como o FB". ${ }^{53}$

Carabina em punho, a chefe da Delegacia de Repressão aos Crimes de Informática da Polícia Civil intima Frank com voz firme e dicção nítida: “Abre a porta, é a polícia, se não a gente vai arrombar!”. A Globo entra para oferecer um MC de cuecas e atônito - sua primeira filha, Yasmin, nascera no dia anterior - a centenas de milhares de espectadores em horário de almoço. A câmera fixa o torso nu de Frank, desce pelo ventre, passa pela virilha, contorna os quadris, desce pelas nádegas e, na altura da coxa, toma o rumo da esquerda, acelerando em direção à superfície horizontal do balcão para focar em big close-up os cordões de ouro meticulosamente dispostos em composição geométrica com o maço de cigarros, o isqueiro, o relógio, o anel, as chaves e a pulseira evidência tácita de "enriquecimento ilícito". "Vai lá no morro falar pros bandidos que não pode cantar", justifica-se Tikão. "A gente canta nossas músicas e nunca foi obrigado por ninguém”, esclarece Frank. O repórter sentencia: "Os dois tentaram se defender, mas entram em contradição".

O plantão jurídico do Tribunal de Justiça do Estado do Rio de Janeiro rejeitou o pedido de habeas corpus em 18 de dezembro. No dia 20, os advogados dos MCs recorreram da decisão para o Superior Tribunal de Justiça. De acordo com a "Ordem de habeas corpus com pedido de liminar impetrada em favor de MCs - Liberdade de Expressão" ${ }^{54}$, a ordem de prisão criminaliza uma manifestação musical cujo direito é garantido pelo artigo $5^{\circ}$ da Constituição Federal de 1988: “é livre a manifestação do pensamento, sendo vedado o anonimato" (Inc. IV) e "é livre a expressão da atividade intelectual, artística, científica e de comunicação, independentemente de censura ou licença" (Inc. IX). Sob a égide da Constituição, a prisão antes do pronunciamento de sentença penal condenatória irrecorrível é medida de caráter excepcional, somente admitida na forma e nas hipóteses previstas em lei. Entre as espécies de prisão provisória encontra-se a prisão temporária, regulada pela Lei 7.960/1989. Ela cabe quando houver fundadas razões de autoria ou participação do indiciado em algum dos crimes descritos no rol taxativo do artigo $1^{\circ}$, inciso III, da

53 Fabiano Atanazio (ou Atanásio) da Silva nunca foi "o chefe da facção criminosa que dominava o Alemão”, mas sim o líder do varejo de substâncias ilícitas na Vila Cruzeiro, Complexo da Penha.

54. O habeas corpus nos foi gentilmente cedido por Fernando Augusto Fernandes. FERNANDES, Fernando Augusto; ANDRADE, Thiago; LOPES, Anderson Bezerra; MACEDO, Renan; MARINHO, Renato Silvestre; PAIVA, Nilson; SIDI, Ricardo. Ordem de habeas corpus com pedido de liminar impetrada em favor de MCs - Liberdade de Expressão. STJ, HC 192.802-RJ (2010/o226895-5), rel. Min. Laurita Vaz. Fernando Fernandes Advogados, Rio de Janeiro, 20 dez. 2010 (acesso restrito). 
Lei 7.960. O inquérito policial versa sobre os delitos de incitação ao crime (Art. 286, Código Penal), apologia ao crime ou ao criminoso (Art. 287, $\mathrm{CP}$ ), indução, instigação ou auxílio ao uso indevido de droga (Art. 33, $\mathbb{9}$ $2^{\circ}$, Lei 11.343/2006), e associação para o tráfico de drogas (Art. 35, Lei 11.343/2006). Nenhum deles consta do artigo $1^{\circ}$, inciso III, da Lei 7.960. $\mathrm{O}$ decreto de prisão carece portanto de amparo legal. Tanto o artigo $5^{\circ}$, inciso XXXIX, da Constituição quanto o artigo $1^{\circ}$ do Código Penal determinam que "não há crime sem lei anterior que o defina, nem pena sem prévia cominação legal”. E nos termos do artigo $5^{\circ}$, inciso LXV, da Constituição, "a prisão ilegal será imediatamente relaxada pela autoridade judiciária". 55

No dia 23 de dezembro, o Ministro Ari Pargendler ampara-se na jurisprudência do STJ, para a qual "o delito de associação para o tráfico de entorpecentes é crime autônomo, não sendo equiparado a crime hediondo", para deferir a liminar, relaxando a prisão temporária dos $\operatorname{acusados}^{56}$. Frank, Max, Tikão, Dido e Smith receberam seus alvarás de soltura na véspera do Natal.

\section{Realidade da favela é que o bagulho ${ }^{57}$ é doido}

A música funk carioca é uma fala cantada ou um canto falado sobre uma base rítmica. Essa fala é a das camadas mais pobres da juventude das áreas sub urbanizadas do estado do Rio de Janeiro ${ }^{58}$. Seu melodismo

55 Para uma análise detalhada, ver PALOMBINI, Carlos. Funk proibido. In: AVRITZER, Leonardo; BIGNOTTO, Newton; FILGUEIRAS, Fernando; GUIMARÃES, Juarez; STARLING, Heloísa (orgs.). Dimensões políticas da Justiça. Rio de Janeiro: Civilização Brasileira, p. 647-657, 2013.

56 PARgEndLER, Ari. Decisão (relativa ao HC 192.802 - RJ). Superior Tribunal de Justiça, Brasília, 23 dez. 2010. Disponível em: <https://ww2.stj.jus.br/processo/ revista/documento/mediado/?componente $=$ MON\&sequencial=13539513\&num_registro $=201002268955 \&$ data $=20110201 \&$ tipo $=0 \&$ formato $=P D F>$. Acesso em: 22 maio 2014.

"O bagulho", termo de gíria: "a droga”, "o tráfico", "a vida no tráfico"; por extensão, "a situação", "o negócio", "a coisa”. Sinônimos: "o contexto”; ou, genérico, “o problema”, isto é, o crime, a prisão. "Estar envolvido no bagulho": participar do comércio de substâncias ilícitas, desempenhar um papel na facção. A versão original da frase aparece na voz de um dos meninos do documentário Falcão, meninos do tráfico: "A realidade da vida é que o bagulho é doido, a realidade da favela é que o bagulho é doido." BILL, MV; ATHAYDE, Celso. Falcão: meninos do tráfico. Rio de Janeiro: Central Única das Favelas, 2oo6. (DVD). Disponível em: <http://youtu.be/ d2CysvIQCS 4 >. Acesso em: 10 mar. 2014.

58 Se o qualificativo "carioca" pode ser considerado inadequado é menos pelo fato de essa música existir em outros estados, com características próprias de fala, tradições musicais e economia local, que pelo papel desempenhado no desenvolvimento do gênero por municípios fluminenses, como São Gonçalo e Niterói. Utilizamos o termo "funk carioca" como designação de gênero, e não de origem. 
deriva tanto das inflexões da própria fala quanto do espaço sonoro local, recortado e colado. Esse procedimento não se aplica somente à melodia, mas constitui a própria tecnologia de uma inteligência ${ }^{59}$ que encontra expressão no gênero musical. Dela se pode dizer, como Gérard Genette diz do estruturalismo ${ }^{60}$ e da crítica literária:

[...] é característico da bricolagem ${ }^{61}$ exercer sua atividade a partir de conjuntos instrumentais que, ao contrário dos do engenheiro por exemplo, não foram constituídos em vista dessa atividade. A regra da bricolagem é "dar sempre um jeito com o que se tem à mão", e empregar numa estrutura nova resíduos desusados de estruturas antigas, economizando uma fabricação expressa a custo de uma operação dupla de análise (extrair vários elementos de vários conjuntos constituídos) e síntese (constituir, a partir desses elementos heterogêneos, um conjunto novo onde, no limite, nenhum dos elementos reutilizados recuperará sua função original). Essa operação tipicamente “estruturalista” [...] compensa certa carência de produção com extrema engenhosidade na distribuição dos restos [...]. ${ }^{62}$

"Realidade da favela", repetem DJs e MCs, o funk carioca de fato o é não apenas ao extrair seus elementos do próprio espaço sonoro, mas também ao organizá-los de modo a constituir um discurso $d a$ favela sobre $a$ favela para a favela. Cabe-lhe "não o papel exclusivo de transmitir imagens e sons, mas fazê-los dizer alguma coisa". ${ }^{63}$ Em consequência, "a imagem de um objeto, a modulação de um ruído já não nos chegam como tais, em função tanto da significação que lhes é associada quanto da sugestão da qual são portadores". ${ }^{64}$ Essa atribuição de sentido coloca em

59 LÉVI, Pierre. Les Technologies de l'intelligence: l'avenir de la pensée à l'ère informatique. Paris: La Découverte, 1990.

6o O estruturalismo também serve para nos desvencilhar da antropofagia: "Como a tecnologia ocidental se espalha pelo mundo, as pesquisas sobre sua significação devem ultrapassar as contradições anteriores para chegar às intenções mais fundamentais e universais, independentes de raízes étnicas e culturas nacionais." HART, John. Préface. In: SIMONDON, Gilbert. Du Mode d'existence des objets techniques. 3. ed. Paris: Aubier, 1989, p. i-xii, p. ii.

61 O termo francês bricolage se poderia traduzir de modo mais vivo pelo coloquialismo "gambiarra".

62 GENETTE, Gérard. Structuralisme et critique littéraire. L'Arc, Aix-en-Provence, n. 26, p. 30-44, 1964, p. 30 .

63 SCHAEFFER, Pierre. Ensaio sobre o rádio e o cinema: estética e técnica das artesrelé, 1941-1942. Trad. Carlos Palombini. Belo Horizonte: UFMG, 2010, p. 67.

64. Idem, ibidem. Os termos "significação" e "sugestão" remetem ao binômio linguagemsigno/linguagem-sugestão, de Frédéric Paulhan. PAULHAN, Frédéric. La Double Fonction du langage. Paris: Félix Alcan, 1929. 
jogo a subjetividade daqueles que a operam, marcada pelo cruzamento traumático da fronteira entre "o asfalto" e "o morro" sob uma retórica de guerra - numa guerra de fato, onde as Convenções de Genebra não vigem $^{65}$. O funk carioca é música, e nas palavras do inventor da música concreta:

A música começa onde se exercem estes dois procedimentos. Distinguir um elemento (escutá-lo em si, por sua textura, sua matéria, sua cor).

Repeti-lo. Repita duas vezes a mesma coisa, é música. ${ }^{66}$

Se a técnica e a linguagem da música funk carioca estão intrinsecamente associadas à reprodutibilidade técnica do som, seu sentido se perfaz na performance em "atos de fala" - dramatizações coletivas de arquétipos do poder e da sexualidade que são outras tantas formas de elaborá-los.

65 Em sua etnografia da circulação noturna de Mr. Catra, Mylene Mizrahi faz uma constatação aparentemente oposta: "A perspectiva Funk é a de que no Rio de Janeiro contemporâneo ocorreu uma inversão do fenômeno como descrito por Velho, e a maleabilidade que era privilégio das elites e que teria se democratizado na Modernidade, se localizaria de fato nos extratos sociais mais baixos. Seus membros é que teriam efetivas liberdades e habilidades para circulação pela cidade, conformando mediadores e pontos de vista privilegiados". O contraste decorre de diferentes objetos de estudo: Mizrahi enfoca um artista que estudou no Colégio Pedro II, trocou o subgènero Proibidão pela Putaria, e "viveu em diferentes áreas do Rio de Janeiro, como Duque de Caxias, Glória, Copacabana e Méier”, antes de ir morar em Vargem Grande; nossa pesquisa está centrada no Proibidão - entendido como aquele segmento da música funk carioca que trata da vida nos diversos escalões do comércio varejista de substâncias ilícitas - durante o período compreendido entre a primeira e a segunda invasões do Complexo do Alemão (2007 e 2010). Ambas as perspectivas são generalizáveis em algum grau, mas se a interpretação de Mizrahi mostra os limites de nossa generalização, a letalidade policial seletiva que acabamos de expor e o fenômeno recente dos rolezinhos restringem o âmbito da generalização contrária. MIZRAHI, Mylene. A Estética Funk carioca: criação e conectividade em Mr. Catra. 2010. ix + $268 \mathrm{f}$. Tese (Doutorado em Antropologia Cultural) - Instituto de Filosofia e Ciências Sociais, Universidade Federal do Rio de Janeiro, 2010, p. 38. Disponível em: <http://goo.gl/UzkmMe>. Acesso em: 5 mar. 2014. Sobre os rolezinhos, ver PINHO, Osmundo. Black Bodies, Wrong Places: Spatial and Morality Politics of Rolezinho Racialized Youth "Invasions" and Police Repression in Public Spaces of Today's Brazil. Texto apresentado no Colóquio do Interdisciplinary Humanities Center, University of California, Santa Barbara, mar. 2014. Disponível em: <http:// goo.gl/LejVGM>. Acesso em: 6 mar. 2004 .

66 SCHAEFFER, Pierre. Introduction à la musique concrète. Polyphonie. Paris, n. 6, p. 30-52, 195o, p. 39 . 


\section{Reprodutibilidade técnica e pan-africanismo}

A base rítmica pode consistir numa combinação de palmas e sons vocais executados por um grupo em círculo ou semicírculo à volta de um corpo que improvisa e rima como em outras manifestações afrobrasileiras $^{67}$. A história do funk carioca, contudo, depende menos dos cocos e da teoria da música concreta do que da inventividade da diáspora africana e dos fluxos e refluxos de suas culturas - de Memphis para Kingston, de Kingston para o Bronx, do Bronx para Miami e de Miami para o Rio de Janeiro - na partilha daquela "engenhosidade na redistribuição dos restos" que a caracteriza.

A prática de animar festas populares ao ar livre com equipes móveis de som (microfone, caixas de som, amplificador, toca-discos, selector, deejay ${ }^{68}$ e veículo para transportá-los) desempenha um papel na formação da música nacional jamaicana, que toma impulso com as primeiras gravações em acetato - feitas em 1957 para alimentar as festas ao ar livre dos sound systems ou sounds ${ }^{69}$ - de versões locais da parte instrumental do rhythm and blues afro-americano do qual essas festas se nutriam: executadas por um selector, tais versions ou $d u b$ plates $^{70}$ serviam de base para improvisações vocais rimadas de deejays cujas referências eram o jive talkin' dos DJs de rádio afro-norte-americanos e a tradição verbal do toasting cantado da Jamaica. Essas versões instrumentais começaram a ser lançadas comercialmente no lado B de compactos de vinil de sete polegadas em 1971.

Clive Campbell tinha doze anos em 1967, quando sua família trocou Trenchtown, em Kingston, pelas colinas de Morris Heights, no Bronx novaiorquino, num influxo de migração jamaicana para o bairro que, devassado pela Cross-Bronx Expressway, presenciava o nascimento de gangues e logo seria assolado pela heroína e por uma onda de incêndios criminosos. Sob o codinome Kool Herc DJ, ele organizou com sua irmã a festa "volta à escola" na área de lazer do prédio onde residiam, 1520 Sedgwick Avenue, em 11 de agosto de $1973^{71}$. No ano seguinte, passou a executar sequencialmente em toca-discos alternados os breaks de gravações de soul e funk da discoteca paterna, ou a prolongar indefinidamente em loop qualquer

67 O fato de o funk carioca não ser executado nesse formato nos espaços que frequentamos indica a que ponto a sociabilidade do grupo que o produz é excluída desses espaços, e a que ponto nos excluimos dos espaços de origem do gênero.

68 Na Jamaica, o disc jockey (DJ) chama-se selector, e o master of ceremonies (MC), deejay, assim grafado para diferenciá-lo de nosso "DJ".

69 Equipes de som jamaicanas.

70 Não confundir dub plate ou $d u b$, o disco, com $d u b$, o gênero musical.

71 Data e local oficiais de fundação da cultura hip-hop. 
break por meio do uso de duas cópias da mesma gravação, uma em cada toca-discos ${ }^{72}$. A interação entre batidas de break (breakbeats) e dançarinos (b-boys e b-girls) em festas de rua ou block parties propagadas pelo grafitti constituiu a cultura hip-hop, na qual se destacaria o rap (rhythm and poetry), associado a tradições afro-derivadas de contar histórias, como o boasting (autoelogio), o toasting (longos poemas narrativo-elegíacos) e o playing the dozens (troca de insultos competitivo-recreativa) ${ }^{73}$.

Intercâmbios entre as culturas negras das Américas acontecem no Brasil desde $o$ ano zero da indústria fonográfica ${ }^{74}$. Em resposta a transformações musicais e políticas, das quais o assassinato do reverendo Martin Luther King em 4 de abril de 1968 e a funkificação do soulnos anos 1960 são marcadores, o soul e o funk norte-americanos passam a ser apropriados ${ }^{75}$ como expressões de identidades oprimidas mundo afora. Se o registro de "Tributo a Martin Luther King"76 por Wilson Simonal, em fevereiro de 1967, é uma indicação nítida do fenômeno, as liquidações das carreiras de Toni Tornado, Erlon Chaves ${ }^{77}$ e Wilson Simonal ${ }^{78}$ na primeira metade da década de 1970 ilustram aspectos da contrarreação. Ao longo das décadas de 1970 e 1980, apropriações radicais do soul, do funk e do rap afro-norte-americanos desenvolvem-se longe da mídia em bailes animados por equipes de som análogas aos sound systems em áreas sub(-)urbanas no Brasil.

72 BREWSTER, Bill; BROUGHTON, Frank. Last Night a DJ Saved My Life: the History of the Disc Jockey. $2^{\mathrm{a}}$ ed., rev. New York: Grove, 2000. p. 208.

73 NORFLEET, Dawn M. Hip-Hop and Rap. In: BURNIM, Mellonee V.; MAULTSBY, Portia K. (orgs.). African American Music: an Introduction. New York/London: Routledge, p. 353-389, 2006, p. 353-354.

74 Para um caso nas primeiras décadas do século 20, ver PALOMBINI, Carlos. Fonograma 108.077: o lundu de George W. Johnson. Per musi, Belo Horizonte, n. 23, p. 58-70, jan./jun. 2011. Disponível em: <http://goo.gl/Gvt5Fc $>$. Acesso em: 11 nov. 2013. DOI: http://dx.doi.org/10.159o/s1517-75992011000100007

75 Sobre as noções de apropriação e ressignificação, ver PALOMBINI, Carlos. Funk Carioca and Música Soul. In: SHEPHERD, John; HORN, David (orgs.). Bloomsbury Encyclopedia of Popular Music of the World. London: Bloomsbury Academic, v. 9 . Genres: Caribbean and Latin America, p. 317-325, 2014, p. 318. Disponível em: <http://goo.gl/DAjP6D>. Acesso em: 7 mar. 2014.

76 SIMONAL DE CASTRO, Wilson. Tributo a Martin Luther King. Brasil: Odeon, 7 BD1126 , jun. 1967 (gravado em fev.).

77 Para os casos de Tornado e Chaves, ver HOMEM DE MELLO, Zuza. "BR-3" (V FIC/ TV GLOBO, 1970). In: 2003, cap. 13, p. 367-39o.

78 Ver ALONSO, Gustavo. Quem não tem swing morre com a boca cheia de formiga: Wilson Simonal e os limites de uma memória tropical. Rio de Janeiro/São Paulo: Record, 2011. ALEXANDRE, Ricardo. "Nem vem que não tem": a vida e o veneno de Wilson Simonal. São Paulo: Globo, 20og. CASSEUS, Greg. The saga of Wilson Simonal. Wax Poetics, New York, n. 8, p. 124-132, 2004. 


\section{Volt Mix}

Na segunda metade dos anos 1980, os bailes começam a ser supridos por vinis de doze polegadas de uma variedade de rap popular no sul da Flórida e em Orlando, o Miami bass. A música funk carioca começa a tomar corpo nos anos 1990 quando as faixas instrumentais desses discos passam a ser usadas como base para raps ou melôs locais nos chamados festivais ou concursos de galera. Boa parte dessas criações, entre elas algumas das mais conhecidas - os Raps "do Silva" (MC Bob Rum), "da felicidade" (MCs Cidinho e Doca), "do Salgueiro" (MCs Claudinho e Buchecha), “das armas” (MCs Cidinho e Doca)-, utiliza como base a faixa "808 Beatapella Mix", do single 8 Volt Mix ${ }^{79}$. Esse disco, talvez a gravação mais influente da fase de formação do novo gênero, não vem da Flórida, mas de Los Angeles. Joe González, historiador do Miami bass, explica:

O electro de Los Angeles e o Miami bass eram muito semelhantes até Jerry Heller ${ }^{80}$ assumir controle do N.W.A ${ }^{81}$, principalmente devido à Macola Records ${ }^{82}$, uma potência na distribuição. Talvez a principal informação, já que passei vinte anos no norte da Flórida, seja a rodovia interestadual conhecida como I-10. Ela vai da Califórnia à Flórida pelo Texas, a Louisiana etc. Assim, a distribuição da Macola estava sediada principalmente na Califórnia e

79 BATTERY BRAIN, DJ. 808 Beatapella Mix. In: 8 Volt Mix. Los Angeles: Techno Hop Records, THR-2o, 1988. Disponível em: <http://i.mixcloud.com/ CHsqNa>. Acesso em: 17 maio 2014.

8 o Gerald E. Heller, superagente que representou Otis Redding, Ike e Tina Turner, Four Tops, Marvin Gaye, Eric Burdon, Creedence Clearwater Revival, The Who, Black Sabbath e outros, antes de tornar-se o mais bem sucedido produtor da era do rap.

81 Niggaz With Attitude, grupo de gangsta rap formado em Compton, Califórnia, em 1986, e dissolvido em 1991. González complementa: "A história do N.W.A com Jerry Heller aconteceu um pouco antes do álbum solo de Eazy E. O single Dopeman estava estourando quando Eazy conheceu Heller, e este queria que ele se concentrasse em música incendiária. Assim, Dr. Dre encomendou a D.O.C. letras niilistas para Eazy, enquanto Ice Cube estava na escola de arquitetura. Isso foi entre 1988 e 1989. Mas, claro, ainda houve gravações de electro bass da Costa Oeste depois, só que em menor escala" (mensagem a Carlos Palombini, 25 set. 2013).

82 Macola Record Co., fábrica de discos e distribuidora de Hollywood, fundada em 1984 por Don Mcmillan, onde artistas novos podiam prensar e distribuir a baixo custo um número reduzido de cópias. Macola teve entre seus clientes The Egyptian Lover, LA Dream Team, The 2 Live Crew, Eazy E, N.W.A, Dr. Dre, Ice Cube, Ice T, Too Short e Mellow Man Ace. 
se espalhava pela I-10, como fez o verdadeiro Rick Ross ${ }^{83}$.[...] Esse disco nunca foi sucesso nos Estados Unidos. Para a maioria dos fãs do Miami bass trata-se portanto de uma raridade. Aquele Brain [cérebro] ensinou mais brasileiros que norte-americanos! ${ }^{84}$

Em 1980 a Roland colocou no mercado a bateria eletrônica TR-808 Rhythm Composer, anunciada como "uma máquina de ritmo revolucionária controlada por computador que oferece até 768 compassos de programação por vez". Ela compreendia sequenciador, acentuação (accent) e dezesseis sons sintéticos: bumbo (bass drum); caixa (snare drum); tom-tons grave, médio e agudo (low/mid/high tom); congas grave, média e aguda (low/mid/high conga); golpe de aro (rimshot); claves (claves); palmas (hand clap); maracas (maracas); cowbell (cowbell); prato (cymbal); chimbal aberto (open hi-hat); e chimbal fechado (closed hi-hat). Esses sons eram editáveis manualmente por procedimentos analógicos (contínuos e gestuais): o bumbo, em intensidade (level), timbre (tone) e extinção (decay); a caixa, em intensidade, timbre, e proximidade da esteira (snappy) ${ }^{85}$; o prato, em intensidade, afinação e extinção; os tom-tons e as congas, em intensidade e afinação (tuning); o chimbal aberto, em intensidade e extinção; as claves, o golpe de aro, as maracas, as palmas, a cowbell e o chimbal fechado, em intensidade. A função "acentuação" também dispunha de controle de intensidade. Após fabricar 12 mil unidades, a companhia retirou a 808 de linha em 1983.

Antes de firmar acordo entre instrumento, sonoridade e cultura de rua no hip-hop, a TR-808 deu à house, ao electrofunk e ao techno nascentes sons mais reais que a realidade mesma. A anedota de Don Lewis sobre o som do prato é ilustrativa. Um engenheiro tropeça ao apresentar-lhe os circuitos. Sua taça respinga chá verde na placa. Ligada a placa, o chá e os circuitos interagem num chio. A equipe emula esse ruído após meses de pesquisa. Por ter sido lançada simultaneamente à primeira bateria eletrônica com amostras digitais (samples), a um quinto do preço, a TR-808 teve a personalidade de seus sons desfavoravelmente comparada à fidelidade da Linn LM-1. Fora de linha, os produtores de

83 Depois que "Freeway" Rick Ross fez fortuna em Los Angeles com a venda de cocaína, o rapper William Leonard Roberts II adotou-lhe o nome.

84. Joe González, mensagem a Carlos Palombini, 18 set. 2013.

85 De acordo com o "Manual de operação", o controle snappy simulava "o som da esteira ao aproximar-se ou afastar-se da membrana inferior". Ver ROLAND Corporation. TR-8o8 Operation Manual. Japan: Roland, [s.d.], p. 4. Disponível em: <http://goo.gl/ Lq9yVJ>. Acesso em: 8 mar. 2014 . 
hip-hop foram encontrar seus pratos, cowbells, caixas e bumbos a preço de ocasião em lojas de produtos usados.

O Volt Mix compõe-se (Figura 1) de uma linha de chimbal fechado, dividindo em quatro a unidade do tempo binário (ou em dois a do quaternário); de uma linha de caixa, marcando as segundas metades de ambos os tempos (ou o segundo e o quarto tempos do quaternário); de uma linha de impulsões ${ }^{86}$, com quatro cliques na primeira metade do tempo forte (ou no primeiro tempo do quaternário); e de uma linha de bumbo, sincopando três das dezesseis divisões do compasso (binário ou quaternário).
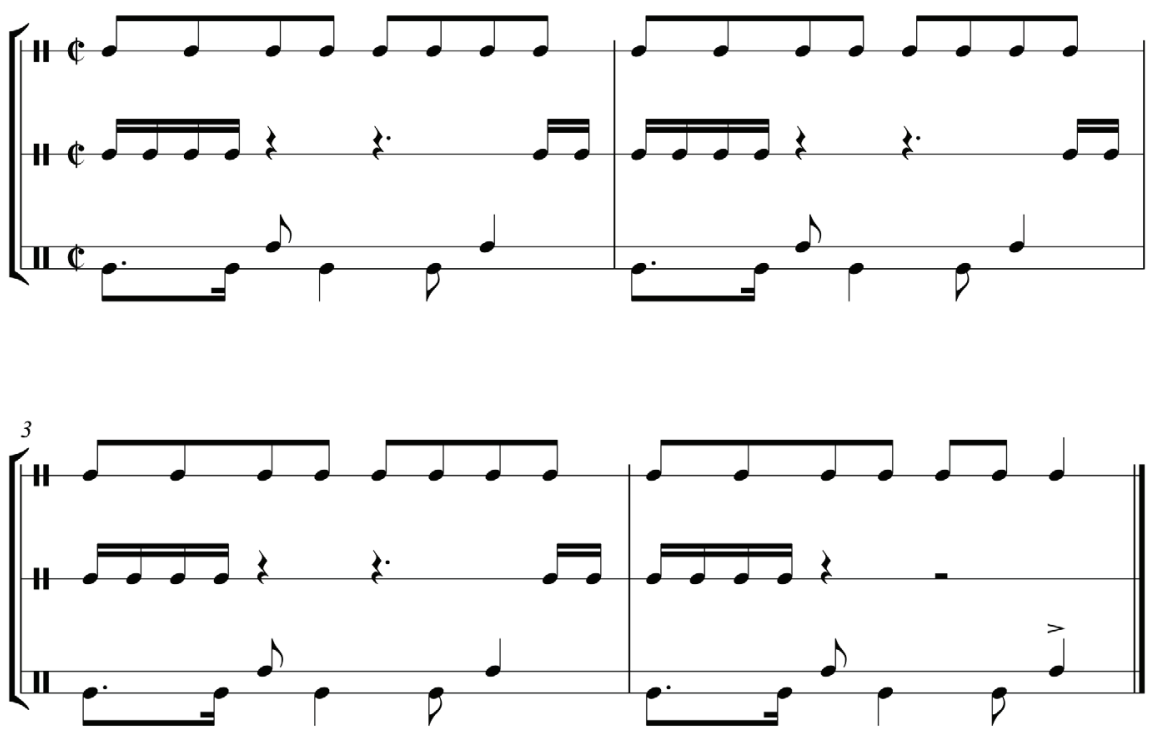

Figura 1: Combinação das linhas rítmicas do bumbo e da caixa (abaixo) com a do chimbal (acima), costuradas pela voltagem (ao centro).

O painel posterior da TR-808 apresentava três saídas trigger independentes e programáveis para trocar informações com outras máquinas - sintetizadores ou sequenciadores. Elas correspondiam, cada uma, a ritmos programados na cowbell (CB), nas palmas (HC) ou na acentuação (AC). O sinal trigger era um pulso positivo de 15 Volts por 20

86 Nas descrições de sonoridade, os termos em itálico remetem a conceitos da tipo-morfologia do objeto sonoro de Pierre Schaeffer. SCHAEFFER, Pierre. Traité des objets musicaux: essai interdisciplines. Paris: Seuil, 1966. 
milésimos de segundo, adequado para ativar entradas trigger ou gate de outros instrumentos. Logo descobriu-se que esse pulso de sincronismo gerava um sinal audível. Uma vez que saídas trigger e entradas de áudio utilizavam o mesmo tipo de plugue, era possível direcionar o sinal para a mesa facilmente. Foi o que fizeram o Masterdon Committee, de Nova Iorque, em Funkbox Party, em 1982 ${ }^{87}$; o Egyptian Lover, de Los Angeles, em "Egypt, Egypt", em 198488; e o DJ Battery Brain, de Los Angeles, em "808 Volt Mix", em 1988 ${ }^{89}$. As impulsões da linha intermediária do Volt Mix correspondem a pulsos elétricos de fato. Exceto o último de cada grupo, seus ataques são duplos (Figura 2).

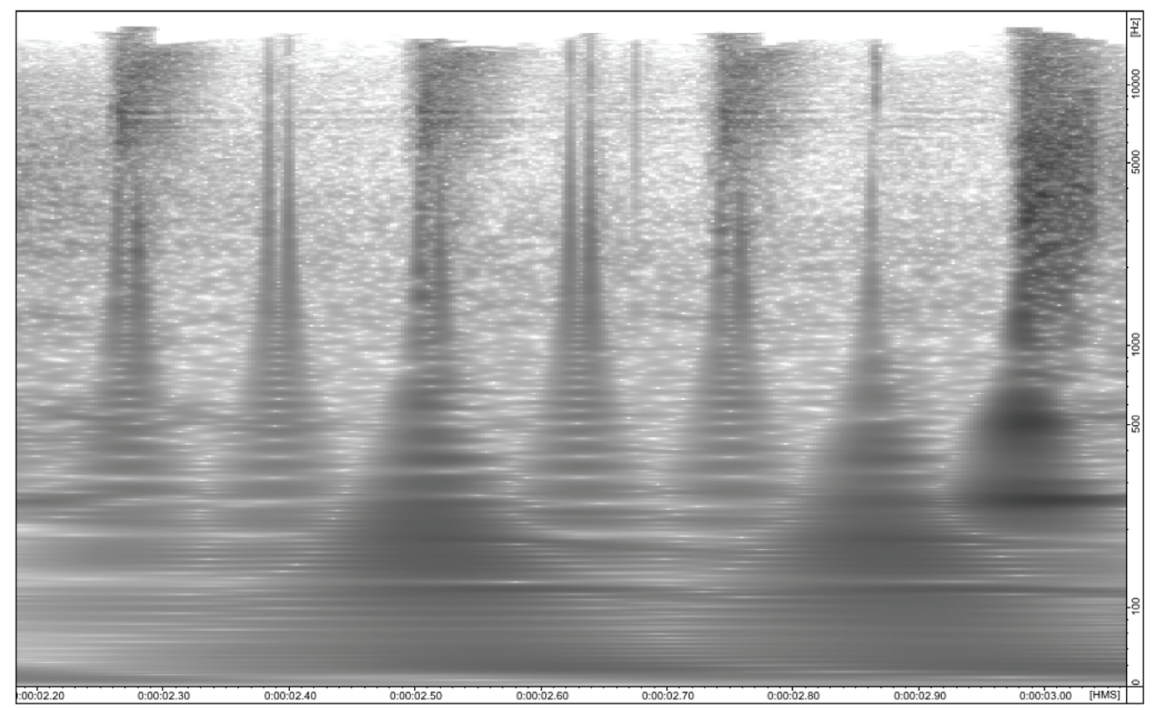

Figura 2: Sonografia das impulsões da voltagem: a primeira e a quinta, duplas, em sobreposição ao chimbal; a terceira, dupla, em sobreposição ao chimbal e ao bumbo; e a sexta, simples, em sobreposição ao bumbo.

87 Masterdon COMmitTeE, The. Funkbox Party. New York: Enjoy Records, EN $603^{2}, 1982$.

88 EGYPTIAN LOVER, The. Egypt, Egypt. Harbor City: Freak Beat Records, DMSR oo66ı, 1984 .

89 As três faixas estão reunidas na mixagem Electro Volt Mix, disponível em: <http://i. mixcloud.com/CHv4vW >. Acesso em: 20 maio 2014. 


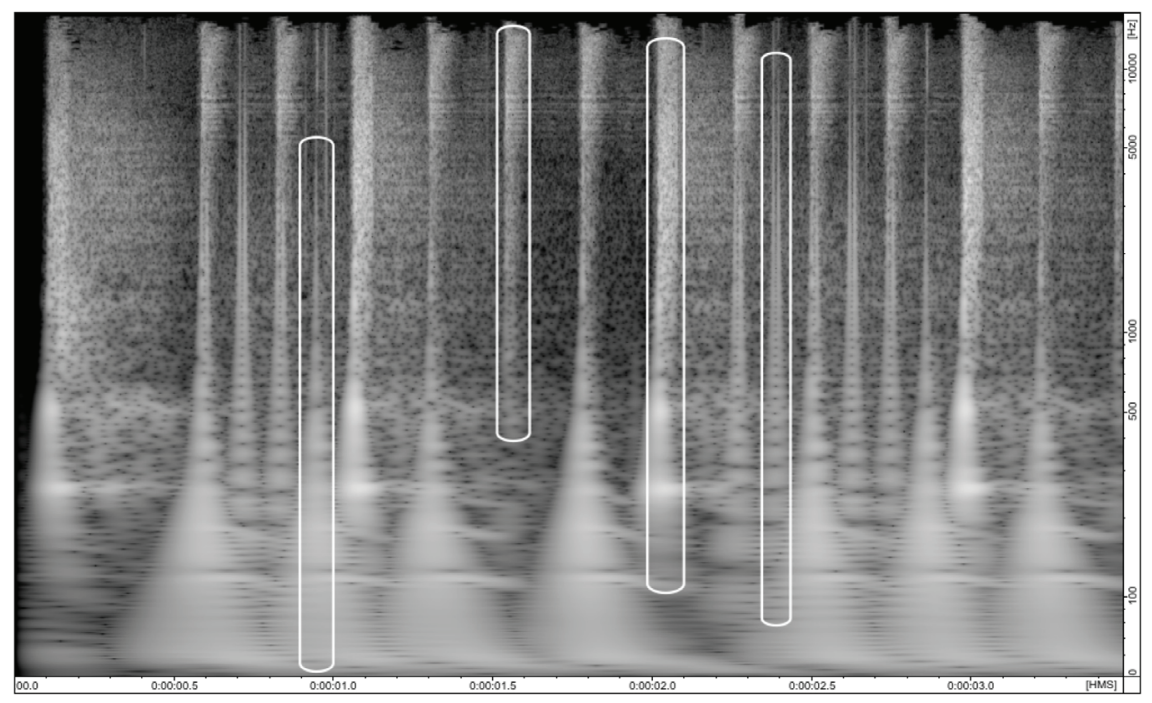

Figura 3: Calibre aproximado, no campo das alturas, das massas do bumbo, do chimbal, da caixa e da voltagem.

As divisões em dezesseis, no grave, em quatro, no médio, e em oito, no agudo, somam-se a diferenças de caráter entre os sons do bumbo, da caixa e do chimbal fechado para individualizar as linhas de uma trama muito aberta e equilibrada, que a voltagem alinhava ao explicitar o máximo divisor comum, e atravessar, com sua massa, três zonas do campo das alturas, sem tocar os extremos (Figura 3).

Não é difícil justificar a preponderância do Volt Mix na fase de formação da música funk carioca: sua textura esparsa oferece amplo espaço à voz; suas divisões múltiplas fornecem ao canto uma rede de apoios; seus sons complexos não impõem tonalidade.

\section{Tamborzão ${ }^{90}$}

A bateria da Mocidade Independente de Padre Miguel parou quando Mestre André (José Pereira da Silva) caiu. Um ritmista - João Branco - começou a repicar ininterruptamente. O Mestre levantou-se,

9o Para a íntegra das transcrições de entrevistas e depoimentos colhidos para esta seção, com exemplos musicais, vídeos, ilustrações e outros detalhes, ver PALOMBINI, Carlos. DJ Luciano: o Tamborzão. Proibidão.org, Belo Horizonte, 4 fev. 2014. Disponível em: <http://goo.gl/Nkwfzv>. In: . Grandmaster Raphael. Ibidem, 2 fev. 2014. Disponível em: <http://goo.gl/5K1YGc>. Acessos em: 6 mar. 2014. 
o repique deu a entrada, e a bateria subiu ${ }^{91}$. A Mocidade Independente inventara a paradinha, que se incorporaria às evoluções de outras escolas nos anos 1960. Herdeiro de Mestre André, Mestre Jorjão (Jorge de Oliveira) conduziu a bateria da Unidos do Viradouro entre 1996 e 1998. Em seu segundo ano na escola de Niterói, ele revigorou o breque com uma variante de uma célula do Volt Mix (Figura 4): "É a inovação, não é? Eu acho que a bateria, para se renovar, tem que inovar. Então, vamos meter o funk". ${ }^{92}$

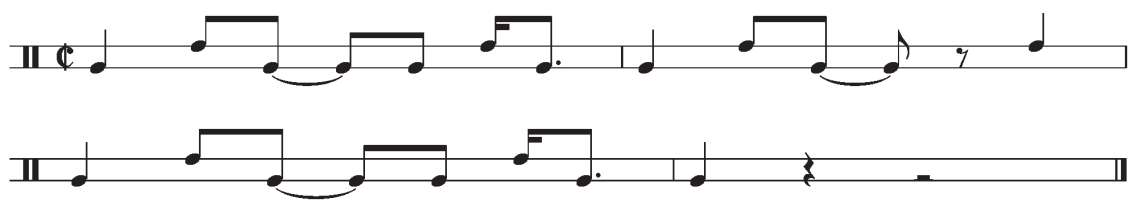

Figura 4: "Paradinha funk" de Mestre Jorjão na bateria da Viradouro em 1997.

Dois anos depois ele diria:

O samba, funk, como esse ano aquele negócio do Villa-Lobos com a orquestra ${ }^{93}$, tudo é a mesma coisa. É só se ensaiar, se combinar: tudo é a mesma coisa. Isso aqui é Brasil. No ano do funk lá na Viradouro, quando botei o funk na gravação ${ }^{94}$, todo mundo foi contra. Naquele ano o funk estava sendo muito criticado pelas violências que existiam..$^{95}$

Para criar, em 1998, o loop que se tornaria conhecido como Tamborzão, o DJ Luciano Oliveira - hoje, MC Sabãozinho - afirma ter se

91 De acordo com o relato por Jorge de Oliveira, no documentário Jorjão, de uma lenda urbana cujas diferentes versões fazem parte da história oral do GRES Mocidade Independente de Padre Miguel. TIEFENTHALER, Paulo. Jorjão. Rio de Janeiro: Synapse Produções, 2004. Disponível em: <http://youtu.be/xGıipmumIPU>. Acesso em: 15 maio 2014.

92 A um jornalista, na Marquês de Sapucaí, apud TIEFENTHALER, Paulo. op. cit. O desfile da Viradouro está disponível em: <http://youtu.be/VMtWtbzVdbs>. Acesso em: 15 maio 2014 .

93 Em 1999, de volta à Mocidade (onde estivera como mestre de bateria de 1988 a 1994), no enredo "Villa-Lobos e a apoteose brasileira".

94 DOMINGUINHOS DO ESTÁCIO; VIRADOURO, Bateria do G.R.E.S. Unidos do. Trevas! Luz! A explosão do universo. In: Sambas de enredo: Carnaval 97 grupo especial. Brasil: Gravadora Escola de Samba Ltda., selo RCA, distribuição BMG Brasil Ltda., 7432144033-2, 1996. Disponível em: <http://youtu.be/tGjtzGZFHEs>. Acesso em: 24 set. 2013 .

95 TIEFENTHALER, Paulo. op. cit. 
inspirado no "funk com instrumentos de escola de samba"96 do Funk'n Lata, de Ivo Meirelles, da ala de compositores do Grêmio Recreativo Escola de Samba Estação Primeira de Mangueira.

DJ Luciano: O lance do Tamborzão começou porque na época em que a gente tocava - não é Cabidão? - usava-se muito o Atabaque, uma batida feita de conga, tipo conga, que o pessoal associava muito ao ritmo que era o do funk da época: o Volt Mix. Naturalmente, como todo o produtor sabe, a gente sempre tem uma necessidade de melhorar, de expandir, de criar sons novos. A R-8 - Ha! -foi a responsável por isso tudo que está aí, não é Cabide? (Mostra a bateria) Foi justamente numa R-8 dessas aí que foi criado o Tamborzão. Acredite se quiser! Na época, quando criei o Tamborzão, foi até engraçado: porque foi de madrugada - devia ser por volta de duas horas da manhã- e bateu uma inspiração louca por causa do Funk'n Lata ${ }^{97}$. Porque o Funk'n Lata sempre teve um som pesadão, e lembro que se começou muito a criar montagens com sons ao vivo, tirados do público, dos bailes: colocava o microfone e gravava os sons. Então falei: "poxa, por que é que a gente não tenta fazer uma batida meio que ao vivão também?" pra crescer, pra dar uma sustentação ao som. Foi quando a gente começou a buscar elementos da bateria eletrônica. Começamos a juntar aquela imundícia toda ali pra ver se dava certo. Aí, foi até engraçado porque, depois que concluí, que fechei a tampa, olhei pra ela, assim, desliguei, e falei: “isso tá uma porcaria!” Ha! ha! ha! ha! Ficou uma semana encostada, uma semana encostada ali, a bateria, até que um belo dia... Eu tinha uma dupla de MCs que, inclusive, moram lá perto da minha casa até hoje. Aí, eles:

96 A descrição é de Meirelles, em entrevista a Monique Evans no programa De Noite na Cama, do canal Shopping Time, da Globosat. Disponível em: <http://youtu.be/ BGudH_laCas>. Acesso em: 15 maio 2014.

97 Em 1998, Ivo Meirelles e Funk’n Lata haviam lançado, ou estavam por lançar: o CD $O$ coro tá comendo, terceiro álbum de Meirelles (o primeiro com o Funk'n Lata); o EP promocional $O$ coro tá comendo/Boquete; a faixa "Voa canarinho"; e "Sobi esse pano, mano", com o rapper luso-moçambicano General D. Tanto "Boquete", faixa de trabalho do CD brasileiro, como "Sobi esse pano, mano" foram divulgadas em videoclipes, disponíveis em: <http://youtu.be/9_tyUyoH6zc > e <http://youtu. be/FSJW9CwtHho>, respectivamente. Acessos em: 15 maio 2014. MEIRELLES, Ivo; FUNK'N LATA. O coro tá comendo. São Paulo: Paradoxx Music, 15080o8-1, 1998. $O$ coro tá comendo/Boquete. São Paulo: Paradoxx Music, Copox 25/98, 1998. MEIRELLES, Ivo; FUNK'N LATA (part. esp.). Voa canarinho. In: Agita Brasil. Brasil: Sony, Epic 981.514/2-490155, 1998. GENERAL D; FUNK'N LATA. Sobi esse pano, mano. In: Onda sonora: Red Hot + Lisbon. Portugal: Movieplay Portuguesa, MOVzo.375, 1998. 
"pô, Luciano, eu tô a fim de produzir um rap". E eu inseri. Foi a primeira aparição do Tamborzão. Foi num rap do Tito e Xandão. E está registrado em CD, o Lugarino apresenta os melhores da Zona Oeste, gravado em $1998^{98}$. Inclusive, é bem interessante falar nisso, o lance da data, porque a gente faz até uma aposta, não é, Cabide? Tenta achar um CD que tenha a primeira aparição gravada. Não vai ter. Foi realmente a primeira música gravada. E depois meu parceiro Cabidão bolado, inspirado - ha! ha! ha! -, fez a montagem da Gota, não é?

DJ Cabide: E foi isso mesmo. Apesar de que você fez aquela vinheta lá, "Novos ritmos, novas galeras". Com certeza, você fez aquele Tamborzão, o patrão Kokota ${ }^{99}$ escutou: "esse tambor... esse tambor que é o tambor do funk, vamos mudar o funk!” Aí, fiz uma montagem da Gota, saiu ${ }^{100}$, e as equipes de som já começaram a copiar. Eu falei: "não, o tambor é o tambor da Zona Oeste, o Luciano criou”. Eu usei aquilo. O pessoal começou a me perguntar: "da onde é aquele tamborzão?" "Aquele tamborzão é o tamborzão da Zona Oeste, feito pelo Luciano". Foi o início do funk. Todo a mundo começou a copiar, a botar nas músicas, e a evolução começou a evoluir, evoluir, evoluir até chegar nesse Tamborzão de hoje.

DJ Luciano: Porque aconteceu foi o seguinte. Quando o Tamborzão foi criado, a gente (no caso, eu), eu passei pra vários DJs, e aí, um vai passando pro outro. Quando o Cabide fez a montagem da Gota, eu lembro bem, teve aquele impacto legal, todo o mundo gostou do som do Tamborzão e, naturalmente, começou a pedir. Foi

98 TITO, MC; XANDÃO, MC. Rap da Vila Comari. In: LUGARINO, DJ. DJ Lugarino apresenta os melhores da Zona Oeste. Rio de Janeiro, 100.oog, 1998. Disponível em: <http://goo.gl/SQLhk4>. Álbum completo em: <http://i.mixcloud.com/ CHIInM>. Os MCs Tito e Xandão haviam registrado o rap "Amor sincero" no LP Hollywood discotheque: a ciência do som, gravado e mixado pelo DJ Grandmaster Raphael em 1995. TITO, MC; XANDÃO, MC. Amor sincero. In: RAPHAEL, Grandmaster. Hollywood discotheque: a ciência do som, v. 8. Rio de Janeiro: Vinil Press, LPVP5042, 1995. Disponível em: <http://goo.gl/cix8U2>. Álbum completo em: <http://i.mixcloud.com/CHrVeq>. Acessos em: 16 maio 2014.

99 Dono da equipe A Gota.

100 CABIDE, DJ Everton. Montagem A Gota. In: EQUIPE A GOTA. A Gota Cerol Fininho Vol. I: o som das galeras. Rio de Janeiro: Equipe A Gota, 1999. Disponível em: <http://goo.gl/kCRFkU>. Álbum completo em: <http://i.mixcloud.com/CHrLIb>. Acessos em: 16 maio 2014. Luciano comenta: "Percebe bem a batida limpinha na intro. Este é o primeiro, o que fiz. 'Uh! Hu! a Gota!' Começa com Tamborzão” (mensagem a Carlos Palombini, 7 out. 2013). 
passando pra um, pra outro, até que veio o festival de galeras lá do Coroado $^{101}$, lá da Cidade de Deus. Foi justamente onde batizaram a batida, no caso, de Tamborzão, porque não tinha nome ainda. Esse festival de galeras marcou muito porque foi de onde saíram os maiores nomes do funk hoje: Tati Quebra-Barraco, Bonde do Tigrão, Bonde do Vinho, vários MCs. E batizaram o Tamborzão. Então o nosso amigo Duda ${ }^{102}$ começou a produzir as montagens, talvez até a pedido dos próprios MCs. Eu não sei bem porque, na época, estava meio ausente. E começou realmente a mudar. Vinha, ainda assim, associado ao Volt Mix. Até que o Tamborzão foi tomando conta, foi tomando conta, foi subindo de volume, vamos colocar assim, e hoje é o ritmo do funk. Quem esperava, não é? Eu não esperava. Esperava, Cabide?

DJ Cabide: Esperava não. Os próprios MCs diziam assim: "Bota aquele Tamborzão, aquele Tamborzão neurótico, bota o Tamborzão!" - que a gente chamava mesmo de Batuque. Era o Batuque, não era o Tamborzão. Os MCs: "Bota aquele Tamborzão neurótico!” Aí pegou. Tá hoje, “Tamborzão”, o Tamborzão do funk. (Corte)

DJ Luciano: Não, acho que foi bem diferente do Volt Mix, porque antigamente os DJs usavam aquele atabaquezinho, era prática já, usar. Que só o Volt Mix, só o Volt Mix... Hoje em dia começaram a ter aquela coisa de agregar sons. Então, usava-se muito aquele atabaque. E o Tamborzão veio mais ou menos naquela linhagem do atabaque. Você vê que a base, tum-papá-pum-pá, não mudou. Só foi agregando, foi só uns agregados. Comecei a baixar, a associar sons de... bastante tumba mesmo. Como é o nome daquele... Não é surdão. Gente, eu esqueço o nome! Ah, vou lembrar depois, que tá ali. Fui modificando alguns pitches também. Na hora da programação mudei os pitches de alguns instrumentos, de alguns sons de percussão. E foi até engraçado porque, confesso, foi meio chutômetro. Fui, "papapá”, e falei: "tá legal, tá bacana”, "não, tira isso aqui", "acrescenta isso aqui agora". E naquela junção ficou um lance bacana porque o som era estéreo. Atualmente o Tamborzão ficou mono por causa do costume de usar Minidisc na época. Nós,

101 Grèmio Recreativo Bloco Carnavalesco Coroado de Jacarepaguá, Cidade de Deus (CDD).

102 Eduardo Silva, o DJ Duda, da CDD. 
DJs, usávamos MD, aparelhos de MD, porque, como o disquete era uma coisa cara, custava um dinheirinho, os aparelhos que a gente comprava, mais modernos, tinham o recurso de usar em mono, não é Cabide? Então, pra aumentar o tempo do disquete, os DJs começaram a criar aquele hábito de gravar tudo em mono. O Tamborzão foi passado de um pro outro. Como só se passava de MD para MD, não tinha o recurso do computador... Tu pode reparar que o som do Tamborzão hoje é mono, bem mono mesmo. Mas era estéreo. Então, poxa, a grande verdade, a grande verdade é que nem eu nem Cabide nem ninguém sabia que o Tamborzão viria a ser o ritmo do funk carioca pro mundo.

DJ Cabide: É, inclusive, os bailes de comunidade hoje em dia, pô, toca o Tamborzão do início ao final, e é aquela batida o tempo todo.

DJ Luciano: Do início ao fim, é do início ao fim, cara!

DJ Cabide: E quando muda, ninguém dança. Nego quer escutar o Tamborzão do início ao fim do baile. No caso de o baile começar dez horas da noite, vai acabar seis horas!

DJ Luciano: Chegou um estágio - é como o Cabide estava falando - que, pra mudar agora, vai levar um tempinho mesmo. Porque o Tamborzão já está bem inserido, e as gerações antigamente levavam mais tempo pra mudar. Uma geração, hoje, uma criança que está com nove anos, daqui a três anos, com doze, treze anos, já está curtindo o funk há um bom tempo, desde os nove. E com treze já está começando a curtir o baile da sua comunidade. E agora, como é que faz? Aí, é complicado. Pra mudar a história do Tamborzão hoje, pra de repente vir a criar um elemento novo ou talvez um ritmo novo, acredito que vai levar mais uns dez aninhos aí. Ha! ha! ha!

DJ Cabide: Dez aninhos... (Corte) Ele explodiu mesmo foi já em 2000. Em 2000 começaram todas as montagens. O pessoal: "enfia batuque!" O pessoal usava o Tamborzão que ele criou e acrescentava mais batidas, mais tambor em cima de Tamborzão. Mas a base, mesmo, é o Tamborzão que tá até hoje.

DJ Luciano: Porque ele deixou de estar ali pelo backstage pra ficar realmente de cara pro gol. O Tamborzão passou a ser o 
elemento principal mesmo, o ritmo do funk. Foi ali que aconteceu tudo. Acho que foi o ano 2001, por aí, 2000, que aboliu o Volt Mix e todo o mundo só queria o Tamborzão, o Tamborzão, o som do Tamborzão... E assim foi embora. ${ }^{103}$

O DJ Duda prestou-nos seu depoimento em encontro de DJs no Bangu Atlético Clube ${ }^{104}$.

O Luciano Sabãozinho! Ele fez a programação de bateria, o Tamborzão, pois não existia o loop, e produziu a primeira música com essa batida. Nem ele nem ninguém acreditava na ideia da batida. O DJ Cabide foi o primeiro a pegá-la e misturar com outros elementos, como o Volt Mix, e começou a criar algumas montagens da Gota com ela ${ }^{105}$. O pessoal não abraçou muito. Os DJs não abraçaram. Como gostei do suingue, que tinha a ver comigo porque sou carioca, filho de baiano, e meu pai é português - a história do Brasil é esta pessoa aqui! -, simpatizei com a ideia da batida africanizada junto com os beats americanos e tudo o mais. Comecei a envolver, a misturar, e a dar voz à comunidade, à favela. Quando comecei a pegar as ideias, comecei a lapidar, mas sempre usando outros elementos. [...] Em 2000 nós explodimos e nos tornamos o que foi: Bonde do Vinho, Bonde do Tigrão, Tati QuebraBarraco, Os Carrascos, uma pancada de artistas. Todos esses caras, que são sucesso ainda e deram a volta ao mundo, saíram da minha mão e da minha ideia. A magia total vem do Luciano. Eu peguei esse produto maravilhoso, comecei a envolver em todas as programações de bateria com as músicas que eu criava, dando voz à comunidade. Nasceram os maiores nomes do funk. Lá na minha comunidade, a Cidade de Deus, onde existe um clube carnavalesco chamado Coroados, naquele palco nasceram muitos dos maiores talentos do funk, e deu-se nome ao Tamborzão, hoje reconhecido como a batida eletrônica do Brasil para o mundo. Foi batizado por mim. A ideia começou a se implantar e hoje é o que é - Tamborzão em todo o tipo de música: na MPB, no samba, no axé music, até

103 LUCIANO, DJ; CABIDE, DJ; IVANOVICI, Tatiana. A história do Tamborzão do Funk. São Gonçalo/estúdio do DJ Cabide, out. 20o6. Disponível em: <http://youtu. be/Ic_AwPMuzkk>. Acesso em: 18 maio 2014 .

104 Somos gratos a Jones MF Jay, policial civil e funkeiro, pelo convite para participarmos do evento.

105 Por exemplo, o “Grito A Gota”, disponível em: <http://goo.gl/Uxkumz>. Acesso em: 18 maio 2014. 
no sertanejo, agora. A página que eu virei, minha contribuição ao funk, acho importante: eu acreditei. E fiz acontecer. Só não tive maldade. Fui roubado por todo o mundo. Também, não tinha experiência... ${ }^{106}$

Após citar o envolvimento de dois dos principais artistas do Miami bass e do Freestyle com o Tamborzão ${ }^{107}$, o DJ Marcelo André sintetiza:

O Tamborzão é uma música dançante, na verdade, um loop de três segundos. E aquilo vai embora, só aquele loop, sem virada, sem nada. Deu certo porque é dançante. O Tamborzão tem a nossa cara, mas se você for lá atrás, a "Melô da macumba" tem um tambor, a "Melô da explosão", também ${ }^{108}$. Era uma coisa leve, não tão pesada e dançante quanto o nosso, mas já tinha o tambor. O que o Sabãozinho fez foi criar uma batida nossa, e todo o mundo no funk copiou. ${ }^{109}$

Decano do funk carioca, o DJ Grandmaster Raphael vê a história sob outro prisma ${ }^{110}$.

O Tamborzão surge de uma mistura de vários samples de percussão. A partir de determinado momento, já na década de 1990 mesmo, começou-se a colocar percussão em cima do Volt Mix: atabaque tirado de discos de produção nacional. Tem um disco de bateria de samba, Alma brasileira, um disco, se eu não me

106 Eduardo Silva, em depoimento a Carlos Palombini e Lucas Ferrari, no encontro de DJs do Bangu Atlético Clube, 25 nov. 2013. In: PALOMBINI, Carlos. DJ Luciano: o Tamborzão. Proibidão.org, Belo Horizonte, 4 fev. 2014. Disponível em: <http://goo. $\mathrm{gl} / \mathrm{Nkwfzv}>$. Acesso em: 11 maio 2014.

107 O produtor musical Anthony Ray Butler ("Pretty" Tony Butler) e a cantora e compositora Trinere Veronica Farrington (Trinere).

1080 costume de dar o título de "melô" às gravações importadas responde à necessidade de identificá-las e citá-las facilmente, a partir de características musicais, ou de homofonia com o título ou a letra original. A "Melô da macumba" à qual Marcelo André se refere é a versão $d u b$ de "Light Years Away", do Warp 9. A "Melô da explosão" é a versão instrumental de "Don't Stop the Rock", do Freestyle. WARP 9. Light Years Away. New York: Prism Records, PDS 46o, 1983. FREESTYLE. Don't Stop the Rock. Miami: Music Specialists, MSI-111, 1985. Disponível em: <http://goo. gl/zgqRrj>. Acesso em: 5 jun. 2014.

109 MARCELO ANDRÉ, DJ; DUARCHA, Claudia. Entrevista: DJ Marcelo André. Rio de Janeiro, Funk de Raiz, 23 maio 201z. Disponível em: <http://goo.gl/flcynv >. Acesso em: 6 mar. 2014.

110 Devemos a Jones MF Jay a realização de mais esta entrevista. 
engano, do próprio AfroReggae, com essas percussões. Começouse a misturar essas percussões com o Volt Mix. Com o tempo, o Volt Mix foi sendo abolido, e ficamos só com a percussão. E aí, mistura daqui, pega de lá... [...] Eu acho que não tem inventor. Acho que tem uma colaboração de vários DJs fazendo uma coisa: eu faço uma coisa aqui, você pega a minha coisa e faz uma adaptação, aí ele pega, já bota outro tempero, e vai copiando, vai copiando, vai adaptando, vai equalizando diferente, quando vê, de um só, virou mil. Acho que é algo mais ou menos assim. [...] Foi surgindo da intuição dos DJs. ${ }^{111}$

Os discursos concordes de Luciano, Duda e Cabide sugerem concepções amalgamadas de autoria individual e coletiva. Marcelo André toma partido pela concepção individual, Grandmaster Raphael, pela coletiva. A ambivalência relaciona-se ao problema do modo de existência do Tamborzão: loop pré-fixado, à maneira do Volt Mix, ou conjunto de traços distintivos sujeitos a uma gama de variações, como o Beatbox? Neste estudo identificamos o loop de Luciano com o "Tamborzão puro" (Figura 5), ao qual conferimos o estatuto provisório de grau zero das variações da base.

Quando o soul da Filadélfia ${ }^{112}$ prefigurava a disco, na primeira metade dos anos 1970, o selo Salsoul lançou "o conceito de combinar o som latino com ritmos de rhythm and blues, e realçar tudo isso com a opulência de cordas da Filadélfia". ${ }^{113} \mathrm{Na}$ era do rap, nos anos 1980, o Miami bass e o freestyle valorizaram elementos "latinos". Quando esses gêneros escasseavam, nos anos 1990, DJs fluminenses passaram a extrair percussões afro-brasileiras de LPs nacionais para incorporá-las ao Volt Mix. Em 1998, um DJ de Campo Grande sequenciou samples de bateria para montar um loop identificado como "batuque". No ano seguinte, um DJ de São Gonçalo utilizou o loop "neurótico" e propagou a montagem por rádio $\mathrm{FM}^{114}$. Um DJ da Cidade de Deus empregou o loop "africanizado" nas produções musicais de um elenco de MCs em ascensão. Um

111 Angelo Antônio Raphael, em entrevista a Carlos Palombini, no estúdio da Vila Valqueire, 25 jan. 2014. A gravação da entrevista está disponível em: <http://i. mixcloud.com/CHlzlD $>$. Acesso em: 17 maio 2014. Para a transcrição, ver PALOMBINI, Carlos. Grandmaster Raphael, op. cit.

112 O soul da Filadélfia, ou Philly soul, foi valorizado no Rio de Janeiro.

113 SHAPIRO, Peter. Turn the Beat Around: the secret history of disco. New York: Faber and Faber, 2005, p. 147.

114. Uma sequência do DJ Cabide na rádio Imprensa FM, provavelmente de 1999, incluindo a "Montagem A Gota", está disponível em: <http://i.mixcloud.com/ CHvaYq>. Acesso em: 20 maio 2014. 
desses grupos participou de um CD de popularidade nacional no ano $2000^{115}$. Porém "só em 2001, com a música 'Tira a camisa', do MC Cabo"116, em produção de Dennis DJ, o Tamborzão se fixou como a batida padrão do funk"117.

Um “Tamborzão puro"118 cristalizou-se em dado instante (Figura 5), mas nunca deixou de conviver com variantes, misturas, explosões, rajadas, rulos e floreios, como ocorria, de resto, com o Volt Mix.

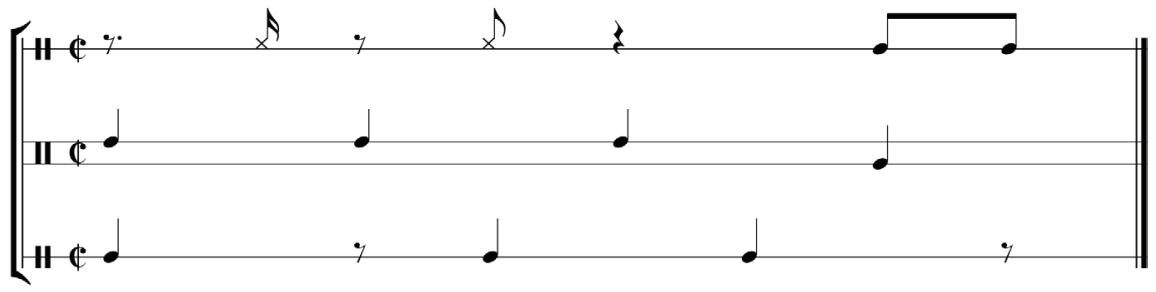

Figura 5: De baixo para cima, o bumbo, os tom-tons e as congas do "Tamborzão puro".

Nas linhas da Figura 5 estão representados, de baixo para cima, o bumbo, os tom-tons (tom-tom grave e surdo de chão) e as congas. Ou, na nomenclatura da R-8, o ambo (ambient) kick, no grave; o attack tom 2 (tom-tom grave da bateria) e o attack tom 1 (surdo de chão da bateria), no médio grave; a slap high conga e a open low conga, no médio agudo. O ambo kick é exclusivo da versão MK-II. Os tom-tons estão incluídos no nono cartão de memória. As congas fazem parte da memória interna da $\mathrm{R}-8$.

O DJ Luciano fornece uma espécie de Ursatz rítmica (Figura 6) ${ }^{119}$ : na linha inferior, "tum", a primeira batida do bumbo, reforçada pela

115 TIGRÃO, Bonde do. Cerol na mão. In Furacão 2ooo: Tornado muito nervoso 2. Rio de Janeiro: House Funk Produções Artísticas, 110204, 2000. De acordo com Rômulo Costa, proprietário da equipe, o CD vendeu entre 200 mil e 400 mil cópias, incluída a pirataria. ESSINGER, Silvio. Batidão: uma história do funk. Rio de Janeiro/São Paulo: Record, 2005, p. 201.

116 CABO, MC; DENNIS, DJ. Tira a camisa. In: Rio Baile Funk: Favela Booty Beats. Frankfurt: Essay Recordings, AY CD o3, jun. 2004. Disponível no final da mixagem Afro-Latin Beat Mix. Disponível em: <http://i.mixcloud.com/CHuAHr >. Acesso em: 19 maio 2014 .

117 Luciano Oliveira, entrevista a Carlos Palombini, 25 jun. 2012.

118 Embora Luciano insista na diferença entre Tamborzão com Volt Mix e Tamborzão sem Volt Mix, a expressão "Tamborzão puro" não aparece em seu discurso. Ela é característica de coleções de bases para DJs. Disponível em: $<$ http://goo.gl/KJH 5 tx $>$. Acesso em: 20 maio 2014.

119 LUCIANO, DJ; CABIDE, DJ; IVANOVICI, Tatiana, op. cit. 
primeira dos tom-tons, na cabeça do primeiro tempo; na linha superior, "pa-pá", as duas batidas slap da conga aguda, a primeira, sozinha no quarto oitavo do primeiro tempo, a segunda, reforçada pela segunda batida do bumbo, no sétimo oitavo do primeiro tempo; na linha intermediária, "pum”, a terceira batida dos tom-tons, sozinha na cabeça do segundo tempo; na linha superior, "pá”, a primeira batida da conga grave, apoiada pelo surdo de chão da bateria, na metade do segundo tempo.

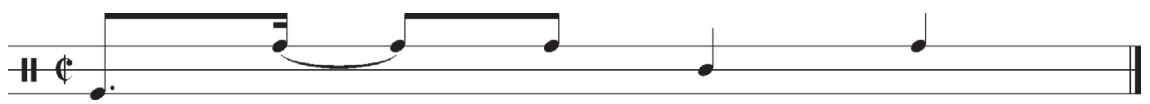

Figura 6: "Ursatz" rítmica do Tamborzão segundo o DJ Luciano Oliveira: "tum pa-pá pum pá".

O DJ Sany Pitbull insere uma variante no segundo tempo (Figura $7)^{120}$ : na linha intermediária, "pum”, a terceira batida dos tom-tons, sozinha na cabeça do segundo tempo; na linha inferior, "pum”, a terceira batida do bumbo, sozinha no segundo quarto do segundo tempo; na linha superior, "pá”, a primeira batida da conga grave, apoiada pelo surdo de chão da bateria, na metade do segundo tempo.

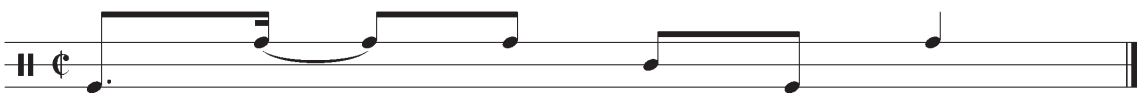

Figura 7: "Ursatz" rítmica do Tamborzão pelo DJ Sany Pitbull: "pum pa-pá pum-pum pá" (preferível: “tum pa-pá pu-tum pá).

Em lugar do realismo fantástico das sonoridades sintéticas da TR-808, o Tamborzão apresenta o realismo propriamente dito das amostras da R-8 MK-II. Em lugar da pele percutida, com ou sem esteira metálica, em lugar dos metais percutidos, em lugar dos rebotes de voltagem, o Tamborzão deixa ouvir peles de calibres distintos percutidas de modos variados. Em lugar da trama de linhas espaçadas e nítidas do Volt Mix, a massa compacta de uma acumulação fervilhante de objetos similares. Sua qualidade propulsiva depende menos das linhas individuais que do enlace dos três ritmos, e do peso do amálgama sonoro, do extremo grave ao médio agudo.

120 DJ Sany Pitbull, apud IVANOVICI, Tatiana; CUNHA, Diogo. Tamborzão por Tatiana Ivanovici e Diogo Cunha. Youtube, canal Ivanovici, 19 out. 20o6. Disponível em: <http://youtu.be/lxiihQSVtLU>. Acesso em: 17 maio 2014. 


\section{Beatbox}

Mímicas vocais, brincadeiras com a linguagem e sílabas "sem sentido", faladas ou cantadas, constituem a base da exploração criativa e estão na origem da própria música: essas vocalizações de alturas, ritmos e timbres fazem parte do comportamento comunicativo do bebê, manifestas desde as primeiras interações ${ }^{121}$. Culturas do norte da Índia, da Coreia e de Cuba utilizam-nas na aprendizagem e partilha de ideias musicais. Elas estão presentes nas percussões vocais do sul da Índia, dos Estados Unidos, da China e de povos celtas ${ }^{122}$.

O beatboxing é a percussão vocal do hip-hop da Nova Iorque dos anos $1980^{123}$, quinto elemento ${ }^{124}$, cujo predecessor é o proto-rap do grupo The Last Poets ${ }^{125}$. Fórmula de acompanhamento ou forma autônoma de expressão, sua prática coloca em jogo - eletrônicos ${ }^{126}$ ou acústicos imitações de bumbo, caixa, chimbal, percussões variadas, baixo, melodia, voz e scratch ${ }^{127}$. O beatboxing começa a rarear nas gravações dos anos 1990, relíquia da Old School ${ }^{128}$ abandonada pelo mainstream, mas permanece na história do gênero a representar o anseio do artista pela fidelidade às raízes ${ }^{129}$.

121 ATHERTON, Michael. Rhythm-speak: Mnemonic, Language Play or Song? Proceedings of the Inaugural International Conference on Music Communication Science. Sydney: ICoMCS, 5-7 Dec. 2007, p. 15-18, p. 15. Disponível em: <http://goo. gl/ACPıuT >. Acesso em: 21 out. 2013.

122 PROCTOR, Michael; BRESCH, Erik; BYRD, Dani; NAYAK, Krishna; NARAYANANET, Shrikanth. Paralinguistic Mechanisms of Production in Human "Beatboxing": a Real-time Magnetic Resonance Imaging Study. The Journal of the Acoustical Society of America, Melville, v. 133, n. 2, p. 1043-1054, fev. 2013, p. 1043. Disponível em: <http://goo.gl/lycTko>. Acesso em: 11 nov. 2013. DOI: http://dx.doi. org/10.1121/1.4773865

123 STOWELL, Dan; PLUMBEY, Mark D. Characteristics of the Beatboxing Vocal Style. Technical Report C4DM-TR-o8-ol. LondON: Queen Mary, University of London, 19 Feb. 2008. Disponível em: <http://goo.gl/92jRdB>. Acesso em: 22 out. 2013.

124. Os quatro elementos canônicos da cultura hip-hop são: discotecagem, break dance, grafitti e rap.

125 LAST POETS, The. The Last Poets. New York: Douglas Records, Douglas 3, 1970.

126 Baterias eletrônicas tiveram o aspecto de caixas até o surgimento da Roland TR808 e da Linn LM-1; daí o nome beatbox.

127 Som obtido por meio da movimentação do vinil, em sentido horário e anti-horário, sob a agulha do toca-discos. O scratch é uma das principais contribuições da cultura hip-hop à técnica da discotecagem.

128 "Old School rap: estilos iniciais de rap que evoluíram na cultura hip-hop, incluindo DJs, um grupo de rappers, dançarinos de break e grafiteiros. New School rap: hip-hop posterior a 1985 , que destaca MCs cujos raps são estilística e liricamente diversos." NORFLEET, Dawn M. op. cit., p. 371.

129 HESS, Mickey (org.). Icons of Hip Hop: an Encyclopedia of the Movement, Music, and Culture. Westport: Greenwood, v. 1, 2007, p. 52. Disponível em: <http://goo.gl/ 
Em seu Dicionário musical brasileiro, Mário de Andrade cita os Tratados da terra e gente do Brasil:

Já Fernão Cardim indica que os índios eram, homens e mulheres, ótimos repentistas. "Arremedam pássaros, cobras e outros animais, tudo trovado por comparações, para se incitarem a pelejar. Estas trovas, fazem de repente, e as mulheres são insignes trovadoras." 130

A onomatopeia percussiva é comum em gravações de samba ${ }^{151}$. "Ziriguidum", de Monsueto, interpretado por Elza Soares e Monsueto no filme Briga, mulher e samba, é um exemplo ${ }^{132}$.

Uma apresentação do MC Mascote do Vidigal na comunidade Rua do Costinha (Campos dos Goytacazes) mostra o uso do beatboxing como recurso improvisado de performance em 2002 $2^{133}$. Mascote o emprega para apoiar, do palco, um coro na plateia, introduzir e complementar o Tamborzão, pedir a base Atabaque ao DJ Flo, reforçar o Volt Mix. Na voz do Charmosinho (atualmente MC Decão), o beatboxing aparece numa roda de funk na quadra do Coroado com Preto de Elite, Yuri dos Hawaianos e Cleber Preto, em registro de Denise Garcia para o filme Sou feia mas tô na moda ${ }^{154}$, em 2004 ou 2005. Charmosinho o utiliza para finalizar a rima e preparar a entrada de Preto de Elite.

O beatboxing passa a exercer o papel de base no funk carioca sob o nome "Beatbox" (inicialmente "Beat Box"). Ele emerge encoberto pelo

PqpyoK >. Acesso em: 22 out. 2013.

130 ANDRADE, Mário de. Dicionário musical brasileiro. Belo Horizonte/Rio de Janeiro: Itatiaia, 1999, p. 188. A referência é ao terceiro tratado (1583-1590) na edição de 1925. CARDIM, Fernão. Tratados da terra e gente do Brasil. Rio de Janeiro: J. Leite \& Cia., 1925, p. 3o6. Disponível em:<http://goo.gl/OJGCCb>. Acesso em: 20 out. 2013.

131 É possível inferir que interações entre culturas musicais afro-brasileiras e afronorte-americanas tendam a colocar o dispositivo em evidência.

132 SOARES, Elza; MENEZES, Monsueto Campos de. Ziriguidum. In: Briga, mulher e samba. Rio de Janeiro: Lupo Filmes, 1961. Disponível em: <http://youtube.com/ watch?v=gefyFIB8ZUI>. Acesso em: 29 maio 2014. SOARES, Elza. Ziriguidum. In: O samba é Elza Soares. Rio de Janeiro: Odeon, MOFB 3235, jun. 1961 (transferência digital EMI, 590051-2, 2003).

133 A data (por volta de 3 de agosto) pode ser inferida a partir da homenagem emocionada ao MC Claudinho: "Três semanas atrás a gente tivemos uma perda muito grande no funk, e um pedacinho do Catra, um pedacinho do Cidinho e Doca, um pedacinho do... foi embora... do Mascote."

134 GARCIA, Denise. Sou feia mas tô na moda. Rio de Janeiro: Toscographics, 2005. Disponível em: <http://youtu.be/NG8J8VkPsFI>. Acesso em: 29 maio 2014. 
Tamborzão por volta de 2008, para tomar a dianteira em 2010 e substituí-lo em 2011. Grandmaster Raphael comenta essa passagem ${ }^{135}$.

Acredito que não tenha sido uma passagem, acho que andam junto, estão sempre em sintonia ${ }^{136} \mathrm{O}$ primeiro Beatbox utilizado em larga escala de produção, digamos assim, foi o do Catra, que é o mais tradicional. O pessoal começou a usar no baile do Jacaré e foi proliferando, as outras pessoas foram fazendo, pegando esse mesmo, acrescentando elementos, modificando. [...] Começa uma febre no Jacaré! E como é que espalha pra não sei onde? Espalha e, quando vê, tá todo o mundo usando. E o dele - modifica a afinação, modifica a equalização, modifica uma coisa aqui - vira centenas, porque todo o mundo vai modificando. [...] A origem é sempre a mesma. ${ }^{137}$

Em reportagem de 15 de maio de 2012 $2^{138}$, Wagner Domingues da Costa (Mr.Catra) clama seus direitos sobre a batida. A polêmica gira em torno da música "Eu quero tchu, eu quero tcha", sucesso da dupla sertaneja João Lucas e Marcelo, composto por Shylton Fernandes, do grupo paraibano Forró Safado. "Já consultei um advogado e ele informou que cabe processo porque o trecho ultrapassa vinte segundos de semelhança”, declara Catra ${ }^{139}$. O MC Créu esclarece:

Essa batida surgiu há mais de dez anos, quando eu nem era MC. Trabalhava como DJ e estava em um baile com o Catra quando o equipamento travou. Falei para ele improvisar enquanto dava um jeito, e ele começou a fazer a batida do funk com a boca. Isso virou hit, foi registrado pela gente, e hoje oitenta por cento dos funks são feitos em cima dessa base. ${ }^{140}$

135 Na tarde de sábado, 25 de janeiro de 2014, em seu estúdio na Vila Valqueire. Gravação disponível em: <http://i.mixcloud.com/CHlzlD>. Acesso em: 18 maio 2014.

136 A comparação entre o que chamamos "Ursätze" do Tamborzão (Figuras. 6 e 7) e nossas transcrições de uma seleção de Beatboxes (Fig. 8-11) fornece evidências em favor do argumento.

137 PALOMBINI, Carlos. Grandmaster Raphael, op. cit.

138 SANTOS, Eliane. Mister Catra acusa sertanejos do "Eu quero tchu, eu quero tcha" de plágio. Ego, Rio de Janeiro, 15 maio 2012. Disponível em: <http://glo.bo/LzuHtR>. Acesso em: 26 out. 2013.

139 Idem, ibidem.

140 Idem, ibidem. 
“Que eu saiba, o ‘tchu-tcha, tchu-tcha' imita o som da batida funk, e não música nenhuma”, responde o advogado da dupla sertaneja ${ }^{141}$. O compositor justifica-se: “Tirei o 'tchu' e o 'tcha' dos gritos de guerra das festas de calouros das faculdades, as calouradas. Juntei isso com a batida funk e fiz a música. Mas essa batida existe desde que o funk é funk. A música é minha". ${ }^{142}$ A matéria inclui um link para uma postagem de "Vem pro cabaré", gravação ao vivo dos MCs Duduzinho e Mr. Catra, acompanhados pelo DJ Belizoti ${ }^{143}$. Transcrevemos a base (Figura 8).

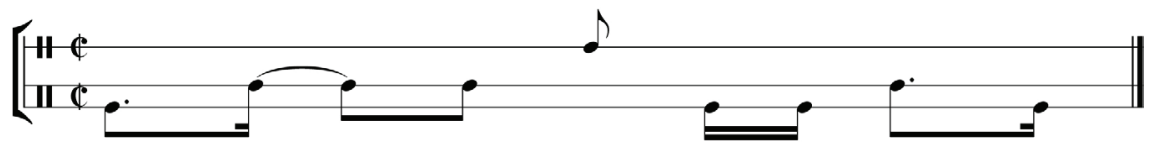

Figura 8: Beatbox 1:"Dum tcha-tcha tz tu-gu tcha tu-".

Três dias depois, em 18 de maio, Catra e o DJ Pigmeu divulgam um loop no Youtube: "Batida produzida por Mr. Catra desde 2003, Beat Box (noventa por cento do funk usa)"; ${ }^{144}$ "Mr.Catra, 'Medley 2011: O papai Tchu! Tcha! Tchu! Tchu!' (Beat Box Catra, noventa por cento do funk usa)". ${ }^{145}$ A base consiste de dois compassos (Figura 9).

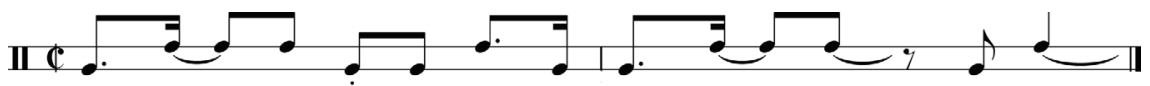

Figura 9: Beatbox 2: "Tu tcha-tcha t-tu tcha tu-tu tcha-tcha tchum tcha" (as ligaduras finais representam reverberações).

Passados três dias, Catra explica-se novamente.

Essa batida, tchum-tcha-tchum, que revolucionou o funk, o Beatbox, foi feita por mim há cinco anos. Uma data em que o Créu

14,1 Idem, ibidem.

14,2 Idem, ibidem.

143 DUDUZINHO, MC; CATRA, MR. Vem pro cabaré. Postagens mais antigas, 20 out. 2011. Disponível em: < http://youtu.be/oibQcEFihqA > (link indicado pela reportagem). Para o loop isolado (embora acrescido de um baixo), ver <http://goo.gl/8HtMO $7>$. Acesso em: 5 jun 2014.

144 Disponível em: <http://youtu.be/Dh4mPVEhgıc>. Acesso em: 26 out. 2013. Uma gravação mais nítida do Beatbox isolado está disponível em: <http://goo.gl/m8GLgU>. Acesso em: 20 maio 2014 .

145 Anteriormente disponível em: <http://youtu.be/AvvRBSnMObk>. Acesso em: 26 out. 2013 . 
nem era MC, era DJ ainda. A equipe dele deu um pau na hora do show e ele falou: "Negão, segura o baile aí!” Eu comecei a fazer esse bagulho e pegou. Enquanto estava no funk, tudo bem. Mas isso é um lance do funk, um lance que revolucionou o funk nos últimos tempos. É uma questão de direito, mano, de direito! O funk já foi tão discriminado, tão sacaneado nos últimos tempos, que chegou a hora da gente correr atrás dos nossos direitos. ${ }^{46}$

As datas de criação variam: "há mais de dez anos" (i.e., antes de maio de 2002), diz Créu; "desde 2003”, o canal Catra divulga; em 2011, indica Pigmeu; "há cinco anos" (i.e., em maio de 2007), afirma Catra.

Esta base (Figura 10) foi coletada em 13 de novembro de 2006. Ela faz parte das 22 faixas da coleção Bases inéditas: vol. 1. Não sabemos precisar a sua origem, a data ou a relação com Catra. A mistura de Tamborzão e Miami bass no conjunto das faixas sugere o Rio de Janeiro da primeira metade dos anos $2000^{147}$.

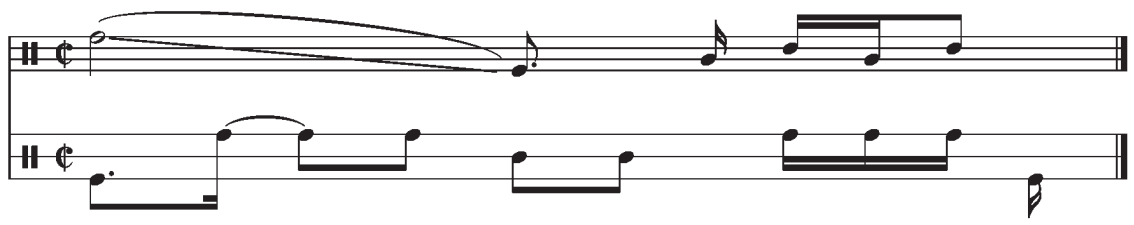

Figura 10: Beatbox 3: a duas vozes, com cuíca; na linha inferior, "dum tch-tch tum-tum tch-k-t tu-".

É o Beatbox mais elaborado que encontramos. No tetragrama superior, em segundo plano, uma cuíca de alturas relativamente definidas e portamento descendente; no inferior, proeminente, um beatboxing sofisticado, com realce de ataques, vogais abafadas, e percussão de consoantes, articuladas com a cuíca: duas linhas com sonoridades diferentes em planos distintos, à maneira de uma Invenção a Duas Vozes. Embora equilibrado, esse Beatbox torna-se inadequado ao papel de base por excesso de originalidade.

146 LOPES, Marcelo. Mr. Catra confirma que vai entrar na Justiça, por plágio, contra a música "Eu quero tchu, eu quero tcha". Site do Marcelo Lopes, Cataguases, 22 maio 2012. Disponível em: <http://goo.gl/jgyFOL>. Acesso em: 26 out. 2013.

147 Disponível em: <http://goo.gl/hEooJl>. Acesso em: 20 maio 2013. 


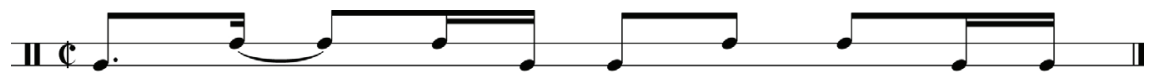

Figura 11: Beatbox 4: "Tum tcha-tcha tu-dum tcha-tcha tu-gu-".

Como executado de improviso por Grandmaster Raphael durante nossa entrevista ${ }^{149}$, "aquele primeiro", do Jacaré (Figura 12), constitui uma variante do Beatbox que Catra e Pigmeu exibem no Youtube em 18 de maio de 2012 (Figura 9).

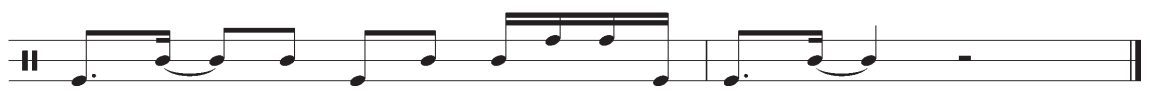

Figura 12: Beatbox 5: "Tu tcha-tcha tu tcha-tcha ki-ti-ku-du tcha".

Como a figura original de Catra se compara com a de João Lucas e Marcelo? (Figura 13)

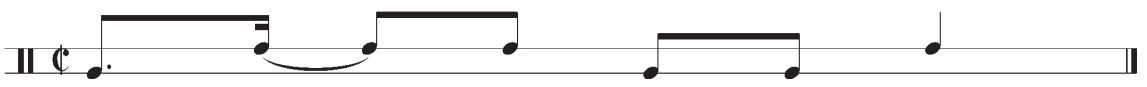

Figura 13: Paráfrase de Beatbox: "tchu tcha-tcha tchu-tchu tcha".

Há citação rítmica literal de quase todo o primeiro compasso, a última semicolcheia do original omitida, mas o "tchu tcha-tcha tchutchu tcha” de João Lucas e Marcelo não é um Beatbox, e, sim, um canto com função de paráfrase alusiva.

O Beatbox abandona o grave e se retrai no médio, onde coincide com a voz do MC. Assim restrito, ele substitui a unicidade de caracteres do Tamborzão pela unicidade do corpo sonoro que é o aparato fonador, e pode recuperar, compactadas no campo das alturas, a diversidade de massas e a nitidez de linhas do Volt Mix.

\section{Análise comparativa}

Primeira base arquetípica do funk carioca, o Volt Mix dispõe três objetos sonoros distintos - evocativos, por síntese analógica, de bumbo, chimbal e caixa - em sítios afastados no campo das alturas, onde formam

148 Postado em 18 jun. 2013. Anteriormente disponível em: <http://goo.gl/viOVjX>. Acesso em: 27 out. 2013. Atualmente disponível em: $<$ http://goo.gl/nVkEJr $>$. Acesso em: 20 maio 2014.

149 Disponível em: <http://goo.gl/Ocgajp>. Acesso em: 20 maio 2014. 
três linhas. Esses objetos obedecem ao modelo percussão/ressonância inerente aos sons percussivos, mas a diversidade dos materiais percutidos, que a síntese analógica emula (pele, pele com esteira metálica, metal), se exprime em massas distintas no âmbito dos sons complexos. Essas diferenças somam-se a diferenças de divisão para imprimir nitidez às linhas. Tais séries de objetos formam uma verdadeira trama cíclica, costurada na tessitura por uma linha de caráter marcadamente eletrônico, a voltagem, cuja massa atravessa o campo das alturas sem lhe tocar os extremos. O Volt Mix evoca um classicismo.

Segunda base arquetípica do funk carioca, o Tamborzão tem como traço distintivo o deslocamento da textura para os registros inferiores. Os objetos constituintes de suas linhas seguem ainda o modelo percussão/ ressonância, mas a unicidade dos materiais percutidos, emulados por análise e ressíntese digital, é compensada não por diferenças de massa, mas por modalidades distintas de ataque e variações de altura, duração e intensidade, tanto no interior das linhas, quanto de uma linha a outra, e também pelos perfis dinâmicos das linhas individuais e de seu conjunto. O efeito é um fervilhar de objetos sonoros no qual as linhas se amalgamam em ímpeto propulsivo, mais acumulação que trama. $\mathrm{O}$ Tamborzão tem o caráter de um expressionismo.

Terceira base arquetípica do funk carioca, o Beatbox se caracteriza pela concentração da textura no registro médio, em sobreposição ao canto. Ele retém a unicidade de corpos sonoros do Tamborzão e a radicaliza em dois tempos: ao substituir uma coleção de corpos sonoros semelhantes, de calibres distintos (bumbo, tom-tons e congas), pelo corpo sonoro único que é o aparelho fonador; e ao irmanar os corpos sonoros da base e do canto. O Beatbox recupera, do Volt Mix, a diferença entre as massas e os ataques dos objetos constitutivos de suas linhas, no interior das quais introduz variedade superior à das linhas do Tamborzão. Por outro lado, ao suprimir os graves, o Beatbox dá continuidade ao processo de redução do calibre da base, mas compensa essa redução ao situá-la na região da fala, onde o ouvido é mais sensível. Seu caráter é o de um modernismo.

Dizer que o Volt Mix evoque um classicismo não é dizer que o funk carioca encontre seu período clássico na infância (embora os saudosistas acreditem nisso). A base é um entre outros elementos da música. Ela serve de apoio ao canto e de pretexto à inventividade do DJ, ao vivo, ou do DJ-produtor, em estúdio. Ele (ou, raramente, ela) pode modificá-la por adição ou subtração de elementos, bem como por corte, repetição ou remontagem de segmentos. A base, como a descrevemos, é um ponto de partida para a criação musical e um complemento do canto. Do Volt Mix, 
dos anos 1990, ao Beatbox, dos anos 2010, acumula-se um repertório de modelos, e o DJ passa, da seleção e manipulação de bases importadas, à manufatura. O Volt Mix, o “Tamborzão puro" e o "Beatbox Catra" são arquétipos sucessivos nos quais a autoridade do original é gradativamente diluída.

Na infância da música funk carioca há contraste entre uma base madura e um canto que se ensaia. Esse contraste tende a diluir-se quando se leva em conta que os traços distintivos do Volt Mix - aqueles que serão retidos - são as sonoridades e células rítmicas da caixa e do bumbo. Na seção final mostramos, em outra perspectiva, o que entendemos por expressionismo.

\section{Sincronismos}

O início do primeiro mandato de Luiz Inácio Lula da Silva coincide, aproximadamente, com deslocamentos e transformações dos espaços dos bailes e com o início do domínio do Tamborzão. No final dos anos 1990, os principais bailes de corredor haviam sido interditados. Realizados nos territórios neutros ${ }^{150}$ de clubes dos subúrbios, esses bailes de luta recreativa, também chamados "bailes de briga" ou "Lado A, Lado B", reuniam grupos de moradores de diferentes comunidades que se aliavam entre si, de modo discricionário, contra outras alianças similarmente formadas. O corpo-a-corpo acontecia ao centro do salão, sob o controle de seguranças, no corredor formado pelo espaço entre as linhas de frente de cada Lado.

É no ano de 1998 que Luciano Oliveira inventa "aquele Tamborzão neurótico". E é ainda - de acordo com o depoimento de um dos informantes de Carla Mattos ${ }^{151}$ - em 1998 que o termo "neurótico" associa-se à facção: por imposição desta, as alianças nos bailes de briga passam a ser compulsórias, e os moradores de comunidades dominadas pelo Comando Vermelho são instruídos a integrar o lado B, enquanto aqueles de comunidades controladas pelo Terceiro Comando ficam vinculados

150 Em contraposição às comunidades de origem dos funkeiros, controladas por uma ou outra das facções, Comando Vermelho Rogério Lemgruber (CVRL) e Terceiro Comando (TC), ou, nos termos pejorativos que lhes são atribuídos pela facção rival, pelos "Cu Vermelho Recheado de Linguiça" e pelos "Três Cu".

151 MATTOS, Carla dos Santos. No ritmo neurótico: cultura funk e performances "proibidas" em contexto de violência no Rio de Janeiro. 2006. 154 f. Dissertação (Mestrado em Ciências Sociais) - Instituto de Filosofia e Ciências Sociais, Universidade do Estado do Rio de Janeiro, 2oo6. Disponível em: <http://goo.gl/Rgc8ıO>. Acesso em: 10 mar. 2014 . 
ao lado $\mathrm{A}^{152}$. Uma vez os clubes interditados, os bailes retornam às comunidades de origem, em guerra com as facções rivais e com a polícia.

A era do Tamborzão tem uma face oculta e uma face visível. A face visível se exprime através da sexualidade sem meias-palavras nas vozes da Cidade de Deus. A face oculta se manifesta em crônicas da "vida do crime". Ela tem seu fastígio e suas obras-primas nos três anos e meio que se estendem da Chacina do Pan à Guerra do Rio. Seu epicentro são os bailes da Chatuba, no Complexo da Penha. Seus temas, o bandido e o código de ética da facção ${ }^{153}$. A Era Lula, a Era do Tamborzão e a Era de Ouro do Funk Proibido se encerram em uníssono com a Guerra do Rio. A paz da facção - o baile - é substituída pela pax romana.

A palavra "paz" designa mesmo, na correlação que estabelece com "guerra" (porque existe ainda um outro sentido, igualmente não metafórico e político, que é aquele em que Kant fala da "paz perpétua"), a priori um tal sancionamento de toda e qualquer vitória, necessário e independente de todas as outras relações jurídicas, e que consiste em reconhecer a nova situação como uma nova forma de "Direito", antes mesmo de saber se essa situação necessita ou não, de facto, de alguma garantia para ter continuidade. Assim sendo, se a violência da guerra, enquanto forma primordial e arquetípica, pode ser tomada como modelo de toda violência para fins naturais, é inerente a todas essas formas de violência e poder um caráter legislador. Voltaremos mais adiante a essa dedução e às suas implicações, pelas quais se explica a tendência do Direito moderno, atrás referida, de retirar, pelo menos às pessoas individuais enquanto sujeitos jurídicos, todo o poder que vise fins naturais. Na figura do "grande" criminoso, o Direito vê-se confrontado com esse poder e a sua ameaça de instituir um novo Direito, uma ameaça que, apesar da sua impotência, nos casos mais significativos faz estremecer o povo hoje em dia como nas épocas arcaicas. O Estado, porém, teme esse poder

152 Idem. Da valentia à neurose: criminalização das galeras funk, "paz" e (auto)regulação das condutas nas favelas. Dilemas, Rio de Janeiro, v. 5, n. 4, p. 653-68o, out./ dez. 2012. Disponível em: <http://goo.gl/rf6Z40>. Acesso em: 10 mar. 2014.

153 De acordo com Ben Penglase, a narcocultura no Rio de Janeiro é uma criação do Comando Vermelho. Penglase sustenta "que o legado mais importante do CV foi um conjunto de símbolos, discursos e as táticas que o grupo produziu”. PENGLASE, Ben. The Bastard Child of the Dictatorship: the Comando Vermelho and the birth of "narco-culture" in Rio de Janeiro. Luso-Brazilian Review, Madison, v. 45, n. 1, p. 118-145, 2008, p. 119. Disponível em: <http://goo.gl/Yutlre>. Acesso em: 11 mar. 2014. DOI: http://dx.doi.org/10.1353/lbr.o.ooo1 
essencialmente pela sua possibilidade de instituir um Direito, do mesmo modo que tem de reconhecê-lo como tal quando potências estrangeiras ou classes sociais o obrigam a conceder-lhes, respectivamente, o direito de fazer a guerra ou a greve. ${ }^{154}$

O duplo mandato de Luiz Inácio Lula da Silva emerge sob as piores luzes quando se observa sua política de segurança pública. Ela foi corresponsável pela música mais original. E tratou de proibi-la.

154 BENJAMIN, Walter. Zur Kritik der Gewalt. Archiv für Sozialwissenschaft und Sozialpolitik, v. 47, n. 3, p. 8o9-832, 1920/1921. Trad. João Barrento. In: BARRENTO, João (org.). Sobre a crítica do poder como violência. Walter Benjamin: o anjo da história. Belo Horizonte: Autêntica, p. 57-82, 2012, p. 65-66. 


\section{Sobre os autores:}

\section{Guillermo Caceres}

Professor de Prática Instrumental e Tecnologia Musical na Universidade Federal do Ceará (UFC, Sobral, CE, Brasil). Bacharel em Piano pela Universidade Federal do Rio de Janeiro (UFRJ), graduado em Produção Fonográfica pela Universidade Estácio de Sá (UNESA) e Mestre em Musicologia pela UFRJ. E-mail: guillermotin@gmail.com

\section{Lucas Ferrari}

Graduando em Piano pela Universidade Federal de Minas Gerais (UFMG). Bolsista PIBIC-CNPq 2013-2014. E-mail: lucasferrarirabelo@gmail.com

\section{Carlos Palombini}

Bolsista de Produtividade em Pesquisa - Nível lC - 2007-2017. Auxílio do Edital Universal Fapemig 2012-2014. Graduado em Direção Teatral pela Universidade Federal do Rio Grande do Sul, Porto Alegre, RS, Brasil (UFRGS), especializou-se em Tecnologia da Informação Musical na City University London (Londres, Reino Unido) e obteve Ph.D. em música da Universidade de Durham (Durham, Reino Unido). É professor de Musicologia na UFMG e membro colaborador do PPGMUNIRIO. E-mail: palombini@ufmg.br

\section{Dedicatória:}

Dedicamos este trabalho à memória de Elizabeth Travassos. 
